Complutense Journal of English Studies

ISSN: 2386-3935

http://dx.doi.org/10.5209/cjes.64263

\title{
Brexit means Brexit: a constructionist analysis
}

\author{
Jose A. Mompean; Javier Valenzuela Manzanares ${ }^{1}$
}

\begin{abstract}
This paper presents a corpus-assisted discourse analysis of the Brexit means Brexit tautology from a constructionist perspective. A multimodal corpus of instances of the construction was compiled and analyzed, paying attention to the components of the construction such as its phonetic-phonological and gestural features as well as the idealized cognitive models underlying the use of the tautology in discourse. This study also addresses how different semantic-pragmatic uses have an impact on the linguistic form (e.g. prosody, gesture) and emphasizes the fluid interaction between linguistic meaning/ form and the social and cultural context in which language is used. It is argued that a full understanding of any construction requires a multimodal, discourse-based analysis.
\end{abstract}

Keywords: tautology, Brexit, construction, multimodality.

\section{[es] Brexit means Brexit: un análisis construccionista}

Resumen. Este artículo presenta un análisis de discurso basado en corpus de la tautología Brexit means Brexit desde una perspectiva construccionista. Se ha compilado y analizado un corpus multimodal de ejemplos de la construcción, prestando atención a componentes de la construcción tales como sus rasgos fonético-fonológicos y gestuales, así como a los modelos cognitivos idealizados (ICMs) que subyacen al uso de de esta tautología en discurso. El estudio también analiza cómo los diferentes usos semántico-pragmáticos tienen un impacto en la forma lingüística (p. ej., prosodia, gesto) y enfatiza la fluida interacción entre la forma/significado lingüísticos y el contexto social y cultural en el que se usa el lenguaje. Se afirma que una comprensión más completa de cualquier construcción requiere un análisis multimodal basado en discurso real.

Palabras clave: tautología, Brexit, construcción, multimodalidad.

Contents. 1. Introduction. 2. A constructionist approach to the study of tautologies. 3. The Brexit means Brexit construction: a corpus-assisted discourse analysis. 3.1. Background. 3.2. Data. 3.3. Method. 3.4. Analysis. 4. Conclusion.

How to cite this article: Mompean, J. A.; Valenzuela Manzanares, J. (2019) Brexit means Brexit: a constructionist analysis, in Complutense Journal of English Studies 27, 1-37.

\section{Introduction}

The referendum held in the United Kingdom (UK) in 2016 on the country's membership of the European Union (EU) was "one of the most seismic political events of the last 50 years..." in British history (Riley-Smith 2018, p. 3). It is therefore unsurprising that what has come to be known as Brexit, or the withdrawal of the UK from

1 Department of English Philology, University of Murcia, mompean@um.es / jvalen@um.es. 
the EU, has attracted scholarly attention in many fields such as politics (e.g. Wincott, Peterson, and Convery 2017), sociology (e.g. Outhwaite 2017), or linguistics (Koller, Kopf, and Miglbauer 2019), among other fields. In this respect, the current study addresses one Brexit-related tautology by the former Prime Minister (PM) of the UK, Theresa May, Brexit means Brexit, from a constructionist perspective.

The term tautology is typically used in linguistics to refer to a statement that is true concerning every possible situation. This is achieved through the repetition of the same lexical or propositional content (e.g. boys will be boys, a deal is a deal). Tautologies have been studied in various languages (e.g. Arabic: Farghal 1992; English: Fraser 1988; German: Meibauer 2008; Japanese: Okamoto 1993; Korean: Kwon 2009; etc). One feature of this body of research is its semantic-pragmatic bias. It is occasionally acknowledged that tautologies show syntactic variation (Meibauer 2008) and a typology of syntactic types has even been proposed (Ward and Hirschberg 1991) but the formal aspect is marginal in most accounts. As for the semantics/ pragmatics of tautologies, they have sometimes been considered to be "totally noninformative" (Grice 1975, p. 52) yet there is widespread consensus that they convey a meaning that goes beyond their truth-conditional value (Emmet 1962). Beyond this, tautologies have been studied from three main approaches that can be described as (radical) pragmatic, (radical) semantic, and hybrid semantic-pragmatic (e.g. Gibbs and McCarrell 1990; Szymanek 2015; Wierzbicka 1987).

The radical pragmatic approach suggests that tautologies are interpreted as conversational implicatures calculable from language-independent conversational principles such as Grice's Cooperative Principle (e.g. Brown and Levinson 1987; Meibauer 2008; Ward and Hirschberg 1991). In this view, tautologies seem to violate the Gricean Maxim of Quantity, which implies that cooperative language users make their utterances as informative as needed and do not produce uninformative or unnecessarily redundant ones. Yet language users normally assume that their interlocutors are cooperative at some deeper level and thus try to infer what they intend to say. In sharp contrast to the radical pragmatic approach, the radical semantic view holds that the meaning of tautologies is conventionalized, context-independent, and not derived from language-independent pragmatic maxims (e.g. Wierzbicka 1987). As a case in point, the English tautology boys will be boys is not used in languages such as French, German, Russian, and a literal translation into a given language (e.g. les garçons seront les/des garçons in French) would not be understood by speakers of that language (Wierzbicka 1987). Thus, “...the 'implicature' of the tautological construction... would not be worked out" (p. 96).

While radical pragmatic and radical semantic views seem incompatible, other hybrid approaches have suggested that tautologies have conventionalized, language-specific meaning but also that language users' inferences play a role in their contextual interpretation (e.g. Farghal 1992; Fraser 1988; Gibbs and McCarrell 1990; Okamoto 1993). This third approach seems to be backed by some psycholinguistic evidence on how tautologies are interpreted by language users. In a study of nominal tautologies in English, for example, Gibbs and McCarrell (1990) made participants rate the acceptability of different tautological constructions either alone or with supporting contextual information. Their results showed that tautologies could be interpreted differently in various contexts, but that there were important regularities in their syntactic form and lexical content influencing how tautological expressions are understood. 


\section{A constructionist approach to the study of tautologies}

The hybrid approaches discussed above represent a step forward in the understanding of tautologies since they acknowledge the relevance of both conventionalization in language and the pragmatic dynamics of context-specific usage events. However, they can be deemed insufficient insofar as they do not fully underline the multiple aspects of tautologies. On the one hand, hybrid approaches tend to neglect their formal aspects by focusing almost exclusively on their semantic-pragmatic component. Little is found in the literature, for example, on the role of prosodic features in the use of tautologies. On the other hand, the existing hybrid approaches do not seem to capture the full extent of the rich cultural cognitive models underlying language use. Some studies (e.g. Autenriech 1997; Gibbs 1994; Gibbs and McCarrell 1990) highlight the importance of language users' stereotypical understanding of people, activities, and concrete objects. In doing so, these studies hint at the importance of conceptual knowledge structures in the study of tautologies, which is otherwise pivotal in contemporary approaches to the study of language, particularly in cognitive approaches to language, where various constructs such as frames (Fillmore 1982), idealized cognitive models (Lakoff 1987), scripts (Schank and Abelson 1977), cultural scripts (Goddard and Wierzbicka 2004), or scenarios Panther and "(Thornburg 1998) have been proposed, among others.", have been proposed.

The current paper aims to provide a more comprehensive analysis of the Brexit means Brexit tautology (henceforth $B m B$ ) that accounts for the multiple cooccurring formal and meaning aspects of tautologies as well as their evolution in connection with the change of social and cultural contexts of use. Unlike most previous accounts of tautologies in language, the paper also aims to reveal any ICMs underlying and motivating the use of the tautology as well as (multimodal) formal aspects such as rhythm, prosody, and gesticulation that characterize the $B m B$ construction.

The approach taken in this paper is a constructionist one within the framework of usage-based linguistics (e.g. Langacker 1987; inter alia.). This approach can also be considered hybrid insofar as language users' understanding of tautologies is “... holistic, emerging from a parallel activation of linguistically encoded and pragmatically salient aspects of meaning" (Marmaridou 2000, p. 225). Constructionist approaches (e.g. Croft 2001; Goldberg 1995, 2006; Langacker 1987; etc.; see Goldberg 2013 for a summary) are suitable for the study of tautologies for at least four reasons. Firstly, they do not prioritize either form or meaning/use but consider both, instead, as equal contributors in shaping linguistic expressions and providing information for the understanding of language as a cognitive and social phenomenon (Fried 2015).

A second reason why constructionist approaches are suitable for the study of tautologies is that they are non-restrictive in their view of both form and meaning. As a case in point, the formal aspect of constructions has been shown to be multimodal; everyday language use and its cognitive representation typically include verbal (i.e. speech) and non-verbal information involving a plethora of audio-visual signals, most notably, co-speech gestures (Holler \& Levinson, 2019; Pagán Cánovas and Valenzuela 2017; Steen and Turner 2013; Vigliocco, Perniss, and Vinson 2014; Ziem 2017; etc.). Constructionist approaches, unlike traditional structuralist or generative ones, consider such multimodal aspects to be a relevant aspect of language. In this, they converge with the emerging and highly interdisciplinary field of multimodal communication studies (e.g. Müller et al. 2013). 
A third reason is that constructionist approaches are comprehensive insofar as they allow an integrated account of the various formal and meaning aspects of constructions, irrespective of their size (e.g. from a single lexical item to multiword phrasal expressions) and perceived regularity or degree of unusualness (e.g. from typical to more peripheral phenomena). Thus, constructionist approaches allow researchers to study language "...in its totality without making any distinction between core and periphery..." (Fried 2015, p. 974). The study of tautologies, therefore, is as worthy of study as any other linguistic phenomenon.

Finally, given their usage-based dynamic nature, constructionist approaches accommodate the study of variation and change in constructions, both in synchronic, real-time (e.g. ongoing discourse) as well as from a diachronic (e.g. language change) perspective. These approaches assume that linguistic knowledge is emergent insofar as it arises from - and is constantly updated in - situated language use in communicative speech events. Given this, constructions differ in their degree of entrenchment and conventionalization (Langacker 1987; Schmid 2016). With repeated use, a novel structure becomes progressively entrenched, to the point of becoming a unit, while extended periods of disuse impact negatively on the entrenchment of constructions. Constructionist approaches, therefore, can be applied to the study of discourse at a given point or over time, as is the case of the current study.

\section{The Brexit means Brexit construction: a corpus-assisted discourse analysis}

The current section presents an analysis of $B m B$ based on a corpus of instances of this tautology in context. Before the analysis, a description of the contextual background (political, social, cultural) and the data for the analysis is provided.

\subsection{Background}

The importance of context in the analysis (see 3.4) requires some preliminary background to the origin and use of $B m B$. This is tied to the referendum held in the UK on 23 June 2016 over the country's membership of the EU. In this vote, British citizens were asked if they wanted the UK to remain a member of the EU or not. With two antagonistic official campaigns, Vote Leave and Britain Stronger in Europe, and faced with two options (Leave or Remain), $51.9 \%$ of voters opted for Leave while $48.1 \%$ voted Remain. The referendum was non-binding for the British government but it decided to implement the result and withdraw the UK from the EU. This should happen following a period of negotiations with the EU after the triggering of Article 50 of the Treaty of Lisbon, which outlines how a country can leave the EU.

One consequence of the result was that the UK's Conservative PM, David Cameron, resigned after having campaigned for Remain. This opened a race for the leadership of the Conservative Party and Home Secretary Theresa May announced her candidacy for the leadership on 30 June. In her announcement, Theresa May (henceforth TM) used $B m B$ for the first time and it seems she may have spent "...the next six months repeating it in answer to just about any question on the UK's exit from the EU" (Geoghegan 2017, p. 3). TM, who became the new PM on 11 July, eventually ceased to use the tautology as often. Yet while most political slogans are ephemeral (Martin 2013), “... some endure as symbols of significant events” (p. 91). This is 
the case of $B m B$, which has been used in the media and the press ever since it was coined, has sparked a series of related - often also tautological - expressions (e.g. Leave means Leave, Remain means Remain, Brexit means Remain, Brexit means Exit, etc.), and has become to some extent a 'meme' (Dawkins 1976) and, more specifically, an 'internet meme' with thousands of hits on Google (304.000 in April 2019).

Another consequence of the result of the referendum was uncertainty about the exact manner in which Brexit would eventually happen. Given the narrow margin of the result, some Brexiters or Brexiteers (i.e. Brexit supporters) feared that the result would be challenged at some point or that Brexit would eventually take an undesirable form for them. Thus, pro-Brexit pressure groups such as Change Britain or Leave Means Leave appeared shortly after the referendum. It is in this context that TM, who had supported the Remain option in the referendum campaign, made extensive use of her tautology as a political statement (or slogan). This was probably an attempt to gain her premiership first and, after that, to keep her party together by delivering "...a form of Brexit that [would] assuage Conservative Brexiters" (Gamble 2017, p. 5). The result of the 8 June 2017 snap General Election in the UK, which May had called in an attempt to secure a majority for her Brexit negotiations, did not help reduce the political uncertainties, since the Conservative Party had poorer results, the Labour Party - led by Jeremy Corbyn - gained more seats and May had to go in a coalition with the Democratic Unionist Party of Northern Ireland.

Regarding the outcome of the negotiations, after Article 50 was triggered in March 2017, a Brexit deal was reached between the UK government and the EU on 14 November 2018. Yet this faced opposition from the beginning from MPs across the political spectrum. One of the most controversial points was the deal's reference to a mechanism (the 'Irish backstop') to prevent a 'hard border' between the Republic of Ireland and Northern Ireland (a part of the UK) until a free trade area came into effect. Critics feared the possibility of being 'trapped' forever in a customs union with the EU despite the fact that TM had promised that the UK would leave the EU's single market and customs union when she released her plans for leaving the EU on 17 January 2017. This type of 'soft' Brexit (the one outlined in the Brexit deal) was strongly opposed by some MPs and members of the general public in favour of a 'hard' Brexit - or exit from the EU's single market and the customs union with or without a deal. By 29 March 2019, the day scheduled for Brexit, the Withdrawal Agreement had been voted down in the House of Commons for the third time and Brexit had not yet been accomplished. Unable to pass her Brexit deal, TM eventually announced her resignation as party leader, which took effect on 7 June while the deadline for the UK's withdrawal was extended to 31 October. Boris Johnson, a former member of TM's cabinet, succeeded her, promising in his first speech as PM that the UK would leave the EU on 31 October with or without a deal.

\subsection{Data}

Most previous studies on tautologies have relied on written texts. In contrast, the current study focuses on audiovisual material since the study of prosody, intonation, and gesticulation requires this type of material. Given this, a small ad hoc corpus of utterances $(\mathrm{N}=36)$ of $B m B$ was compiled from various online sources such 
as video-sharing websites or online versions of newspapers. The utterances were produced by 19 different speakers and include political interviews, contributions, and exchanges in parliamentary sessions, press conferences, rallies, interviews with the media, etc. They are, for the most part, examples of political discourse, defined not only as the talk of politicians but also "... of all other groups, institutions or citizens as soon as they participate in political events" (van Dijk 1997, p. 15). All instances of $B m B$ and related ones by speaker, chronological date of production and an associated link are found in the Appendix as well as the excerpts listed or quoted in the main text.

The size of the corpus is relatively small given the criteria used for building the corpus and the historical period analysed. One particularly stringent requirement was gathering multimodal data - ideally including the visibility of speakers' upper torso and arms. Moreover, data were required to be situated in the social, political context of the post-referendum and produced by known language users that were part of this context. This excluded instances of the tautology in code-switching in other languages, the use of the tautology by the non-British public outside the UK, or instances of the tautology by unknown speakers, dates, contexts, or a combination of these. Finally, the relatively short period under study (2016-early 2019) and the strong association of the tautology with a specific time and political circumstances (mostly 2016) also limited the sample's size.

The current use of massive written synchronic corpora for linguistics research may give the impression that using a small corpus is unrepresentative and outdated. Yet for the vast majority of linguistic questions that linguists may ask (e.g. dialectal variation, historical development, language acquisition, multimodal interaction, etc.), large corpora are not available (Ross 2018). An inspection of the available sources made it increasingly more and more difficult to find any more cases of the $B m B$ tautology following the multimodality and situatedness criteria mentioned above. Yet, while the number of instances do not allow statistical analyses to explore linguistic or phonetic variables as is typical in a great deal of corpus linguistic, sociolinguistic or psycholinguistic work, we consider that the corpus is big enough for the aims of the analysis and to illustrate not only the multiple cooccurring formal and meaning aspects of tautological constructions but also, in the case at hand, of the fluid interaction between social features and linguistic forms, revealing how language and social factors are inextricably related.

\subsection{Method}

The analysis presented can be considered as a corpus-assisted discourse analysis of $B m B$ from a constructionist approach. This analysis combines corpus-assisted discourse analysis (e.g. Baker 2006; Partington 2008), with the use of co-text and context-based information, and a constructionist approach to linguistic analysis (Croft 2001; Goldberg 1995). The use of actual language data from discourse is appropriate given that, in its rejection of the idea of language as "an idealized subset of core linguistic expressions" a usage-based constructionist approach "...makes a commitment to exploring language in its authentic manifestations and puts emphasis on empirically grounded analysis", including "...data that can shed light on the role of discourse structure and the socio-pragmatic dimension [emphasis added] of linguistic organization" (Fried 2015, p. 978). 
The analysis also uses concepts such as those of Idealized Cognitive Model (ICM) in the sense of Lakoff (1987), that is, a sort of frame that can characterize a small conceptual domain or be extensive enough to function as a folk theory or even a narrative structure. As Geeraerts (2003) points out, language users think about social reality in terms of such models, to some extent simplistic or idealized, but used to make sense of intrinsically more complicated phenomena. These models partially represent the knowledge, beliefs or expectations of a given cultural group about an aspect of reality or their interpretation thereof.

Regarding the formal analysis of the data, use was also made of the free speech research software SFS/ WASP (ver.1.54), developed at UCL (www.phon.ucl.ac.uk/ resource/sfs/wasp.php), particularly of spectrographic displays of the tautology and surrounding context. For the analysis of gestures, traditional approaches typically rely on gesture typologies (e.g. McNeill 1992) including, among others, iconic gestures, beat gestures, metaphorical gestures, deictic gestures, and cohesive gestures. More recently, less emphasis is made on discrete categories and more on dimensions such as iconicity, indexicality, and metaphoricity (e.g. McNeill 2005). In the current study, however, special emphasis is made on the distinction between representational (or referential) gestures - including McNeill's iconic, metaphoric and deictic gestures or those that represent properties of referents - and beat gestures, non-representational gestures typically associated with rhythmic marking, focus marking, and discourse structure marking (MacNeill 1992).

\subsection{Analysis}

\subsubsection{Meaning/use}

$B m B$ is a nominal (or equative) tautology, that is, a tautology that denotes two equal noun phrases. Thus, an essential semantic aspect of the $B m B$ construction is the nominal element Brexit, apparently coined in 2012 (Moseley 2016) as a morphological blend of Britain/British and exit and possibly modelled on the earlier Grexit blend, which refers to the hypothetical withdrawal of Greece from the Eurozone given the country's financial struggle some years ago. Brexit is a lexical construction itself, denoting the UK's exit from the EU, and encapsulates an event meaning that "encodes both... exiting as an event and the agentive meaning of who/what will be doing the exiting" (Fontaine 2017, p. 8). Moreover, the conventionalized meaning of Brexit reveals the ongoing, usage-based process of entrenchment of constructional knowledge, grounded in the social, cultural and political scenario that goes from the years and months before the 2016 referendum to the aftermath of that referendum. Thus, the original meaning of Brexit implied a hypothetical scenario of the 'possible' withdrawal of the UK from the EU. In her study of the term Brexit in a news corpus from 2012 to May 2015, Fontaine (2017) found that a hypothetical meaning was encoded in the term - as revealed by the use of collocates such as possible, potential, etc. In this respect, we can talk of a HYPOTHETICAL BREXIT ICM. After the 2016 referendum result and the British government's decision to deliver on that result, the term Brexit acquired a factual meaning of eventual withdrawal of the UK from the EU. The BREXIT ICM can be said to have evolved from a hypothetical version to a factual or real one, a sort of FACTUAL BREXIT ICM. These two ICMs can be sketched as follows: 
The UK has been part of the EU for many years but a referendum in which British citizens can express their opinion can end this. If the Leave option wins, the UK will leave the EU (i.e. Brexit). The future relationship between the UK and the EU would be decided at a later stage.
The Leave option won in the $2016 \mathrm{EU}$ referendum. The margin was narrow but clear. Brexit will now be a reality. The details of the exit are currently unknown immediately after the referendum, but negotiations between the UK and the EU will then take place.

The pre- and post-referendum meanings of the term Brexit and corresponding ICMs, that is, hypothetical Brexit and real Brexit, point to the importance of the context of situation in the entrenchment of a conventionalized meaning but also reveal the non-compositional nature of constructions. In other words, the meanings of Brexit are not simply derived from the elements of the blend (i.e. Britain/British and exit). This is even clearer in yet another use of the term Brexit as 'an iconoclastic and unprecedented vote' (Blitz 2016), evinced by Donald Trump's statement in autumn 2016 that becoming US president would be Brexit plus plus plus, as exemplified fully in (1) in the Appendix.

As for the meaning of Brexit in the $B m B$ construction, it refers to the eventual withdrawal of the UK from the EU (the tautology was, after all, coined after the referendum). Yet one key aspect of the construction is that the actual meanings of the two instances of Brexit in the tautology are not the same. It has been pointed out that the first nominal in tautologies denotes an individual or category while the second denotes some (relevant) properties associated with the former (Rhodes 2009). The relevant properties can be considered to be stereotypical or prototypical of the category (Gibbs 1994; Gibbs and McCarrell 1990; Kwon 2009). Thus, the meaning of tautologies is based on a CATEGORY FOR SALIENT PROPERTY (Csabi and Kövecses 2014; Gibbs 1994) or WHOLE FOR PART (Radden and Kövecses 1999) metonymy, whereby the category of members stands for a typical attribute of the category such as 'unruly behaviour' in boys will be boys or 'supportiveness' in friends will be friends. ${ }^{2}$ An interpretation of the tautology friends will be friends, for example, would imply that 'all friends have the properties of supportive friends'. In the case of $B m B$, the relevant property denoted by the second nominal is the factual exit of the UK from the EU (as opposed to a hypothetical exit), a very relevant feature of Brexit given the referendum results. Thus, the tautology can be read as 'Brexit means actual (not hypothetical) Brexit'.

The metonymic grounding of tautologies can also be applied to the contextual interpretation of tautological expressions, which may seem to vary from situation to situation. Discourse analysts in the radical pragmatic tradition typically assume a speech-act (or Gricean) approach. In this view, language users infer the communica-

\footnotetext{
In this respect, nominal tautologies are akin to contrastive focus reduplicative constructions (e.g. Ghomeshi et al. 2004; Valenzuela, Hilferty, and Garachana 2005) such as it's tuna salad, not SALAD-salad. These constructions are often found in discourse when language users want to indicate the prototypical meaning of the repeated word or phrase as a point of reference for the comparison of a specific case. In such reduplications, the first component, which acts as a modifier, stands for the typical and salient features of the thing referred to while the second component simply denotes the referent.
} 
tive intentions of other language users when performing indirect speech acts, that is, speech acts in which an utterance that contains the illocutionary force of one type of illocutionary act also performs a different illocutionary act (e.g. Searle 1975). Yet as Panther and Thornburg (1998) point out, this approach is insufficient to explain why such inferencing is sometimes carried out almost effortlessly. It does not specify either what kind of inference patterns are used or their cognitive grounding. Moreover, some evidence shows that inferencing does not derive non-literal meaning from a literal one (Stefanowitsch 2003 for a discussion). Given this, an alternative approach relies on conceptual metonymies as facilitators of the inferential work of language users. This is possible given illocutionary (or speech act) scenarios, which are essentially ICMs of certain culturally entrenched activities that include the event as well as the preconditions, components and outcomes of the event (Panther and Thornburg 1998, 2005), and which lead to illocutionary (or indirect speech act) constructions (del Campo Martínez 2011, 2013; Panther and Thornburg 2005; Pérez-Hernández 2012, 2013; Pérez-Hernández and Ruiz de Mendoza 2011; Ruiz de Mendoza and Baicchi 2007; Stefanowitsch 2003; Vassilaki 2017; etc.). Illocutionary constructions, which are inherently tied to a specific illocutionary force, vary in their degree of conventionality, from highly conventionalized ones - and thus not 'indirect' speech acts at all - to non-conventionalized ones that require inferencing. Yet their illocutionary value is permanently associated with them if there is frequent use of the specific form-meaning pairing. A high degree of conventionalization could lead to language users not needing to make use of inferential mechanisms to arrive at an expression's illocutionary value (Ruiz de Mendoza and Baicchi 2007).

The current analysis considers tautologies to instantiate indirect speech act constructions and shows how $B m B$ is used both as a conventionalized indirect speech act construction and as a less conventionalized indirect speech act construction. In the first case, $B m B$ can be said to instantiate an ACCEPTANCE ICM, as used mostly by $\mathrm{TM}$ and her collaborators. In the second case, $B m B$ instantiates an OPPOSITION ICM, as used by many of those who were supposed to accept Brexit but questioned it for some reason. Moreover, the discourse-based analysis reveals the ongoing 'reframing' (Fillmore 1982) of the tautology, once the motivating circumstances change from an appeal to accept Brexit to the questioning of that appeal/acceptance. This questioning derives from the perception of lack of a plan to implement Brexit or from a different view on how Brexit should be delivered.

\section{ACCEPTANCE ICM}

According to Wierzbicka (1987) equative tautologies with abstract nouns "...convey a sober attitude towards complex human activities that must be understood and tolerated" (p. 105). For Rhodes (2009), many tautologies evoke Fillmore's (1982) ACCEPTANCE FRAME, referred to in this paper as ACCEPTANCE ICM. This ICM implies an ACCEPTOR who demands acceptance from an ACCEPTEE, who would normally be expected to be somewhat reluctant to accept the message in the tautology but does not cause many problems (Rhodes 2009). For example, in a given speech interaction between two language users, one user (the 'acceptor') could use war is war to express that his/her interlocutor (the 'acceptee') should accept the fact that wars always imply collateral damage. In the case of $B m B$, the tautology seems to convey the idea that Brexit is unavoidable and that it needs to be accepted by those who opposed it. 
This use is found in many instances in the corpus under analysis and can be considered to be a conventionalized use of tautology. A case in point is TM's first use of the tautology while announcing her candidacy for the leadership of the Conservative Party:

(2) Theresa May (30 June 2016, speech announcing her leadership candidacy in London).

"Brexit means Brexit. The campaign was fought. The vote was held. Turnout was high. And the public gave their verdict. There must be no attempts to remain inside the EU, no attempts to rejoin it through the backdoor and no second referendum. The country voted to leave the EU and it is the duty of the government and parliament to make sure we do just that."

The inevitability expressed by the tautology is reinforced, co-textually, by references in the shape of warnings to opponents that no attempts be made at frustrating the popular mandate. The ACCEPTANCE ICM is also made explicit in a statement by Sajid Javid, Secretary of State for Housing, Communities and Local Government at the time, in a reply to Tristram Hunt (Labour MP), who had questioned Javid about EU funds after Brexit:

(3) Sajid Javid (18 July 2016, House of Commons).

"First, the hon. Gentleman should just accept that Brexit means Brexit. The focus of the whole House should be on how best to deliver that."

According to Rhodes (2009), what is to be accepted in nominal tautologies is a salient problematic characteristic of the people, things, or events denoted by the nominal. In $B m B$, the salient 'problematic' characteristic is the obstacles the process might face. To reassure her audience, then, TM often uses the $B m B$ tautology in the corpus surrounded by co-textual material stressing the idea that she and her government would "make a success of it [the Brexit process]", as seen in examples (4)-(10) in the Appendix.

Other than TM, acceptance is implied in some of her collaborators and party members' use of the tautology to 'enforce' the acceptance of Brexit. These language users also suggest that the acceptance requires everyone to "move on" or "get on with it" in a subsequent stage of the Brexit process. This is exemplified Amber Rudd, Secretary of State for Energy and Climate Change, and Conservative MP Charlie Elphicke, in examples (11)-(12) in the Appendix. The Secretary of State for Foreign and Commonwealth Affairs, Boris Johnson (BJ), also mirrors TM's rhetoric and even hyperbolizes it:

(13) Boris Johnson (2 November 2016, speech at the Spectator Awards, London). "In the words of our great PM, they understand that Brexit means Brexit and we are going to make a titanic success of it."

Finally, as revealed by the use of expressions such as "I couldn't be clearer" or "we must continue to be very clear" - in examples (5) and (9) in the Appendix, respectively -, TM also conveys the idea that the tautology is used not only to elicit acceptance but also to clarify the meaning of what is to be accepted, that is, the UK's 
withdrawal from the EU. This clarification may also explain why the verb mean is used in $B m B$ as opposed to be, which is the default one in equative tautologies. A form-meaning interaction, therefore, seems to apply here. Fraser (1988) has pointed out that be in the future tense in tautologies with nominals denoting humans (e.g. boys will be boys) is to be interpreted as 'to act/behave like' (Fraser 1988, p. 219). In the case of $B m B$, mean can be interpreted as 'make no mistake about the meaning of Brexit, that is, the actual withdrawal of the UK from the EU'. This could be interpreted as a directive speech act in the classical speech act literature or to a similar type of illocutionary force. In this respect, the tautology can be interpreted as a command that can be paraphrased as follows: "you have to accept that the meaning of Brexit is: the UK will inevitably leave the EU. Brexit means nothing different. Make no mistake about it'.

\section{OBJECTION ICM}

Even the explicit use of the verb mean in the $B m B$ tautology may have been insufficient to clarify the meaning or intentions of the UK Government despite their purported claim of clarity. Thus, $B m B$ is often found in contexts in which those supposed to accept Brexit perceive a lack of clarity or a plan. It seems as if many of those who are supposed to accept tautologies without causing much trouble (Rhodes 2009) sometimes do have an issue or objection with its meaning. Consequently, they often express this using a new frame that we could call an OBJECTION ICM. In this ICM, an OBJECTOR finds fault with some action carried out or an utterance produced by someone and expresses his/her objection to it. This ICM is very general but can be specified, for example, as a QUESTION ICM in which the OBJECTOR simply finds the action or statement difficult to understand and demands clarity, or a CRITICISM ICM in which the OBJECTOR expresses disapproval of the action or statement. In this latter case, tautologies may combine with ironic, mocking, and even anxious/angry overtones, depending on the context. In the case at hand, an OBJECTION ICM seems to have been activated in connection with the $\mathrm{BmB}$ construction as a likely consequence of the fact that, after the 2016 referendum, TM did not immediately follow up with a detailed blueprint. Instead, her use of $B m B$ was merely accompanied by references to the fact there would be no second referendum nor attempts to remain in the EU, and that they would get the best deal for the UK, without further specification.

The initial lack of a well-developed plan seems to have been an increasing backlash on TM and her collaborators from autumn 2016 on. This was anticipated by Mark Mardell, presenter of The World This Weekend on BBC Radio 4 in an article published on 14 July 2016 (Mardell 2016) in which he claimed that “...Mrs. May's slogans... seem firm and unambiguous, but after a little reflection unravel into a world of trouble ahead" and that "the manner of withdrawal and the subsequent relationship" between the UK and the EU was "up for grabs". In an online post on 5 September 2016 on a parliamentary report on the progress of the Brexit process, MP Pat McFadden (Labour) claimed: “....the phrase 'Brexit means Brexit' has passed its shelf life". McFadden believed that there was then "zero direction of travel beyond what has already been released" (ibid). Nine months later the situation did not seem any better. In discussing the results of the 8 June 2017 General Election in the UK, Frost (2017) pointed out: "...the level of uncertainty surrounding 'Brexit' has only grown since the snap General Election” (p. 487). 
In the corpus under analysis, the tautology is used as an answer to interlocutors' doubts or used to point out those doubts. This happens often in the context of talk on politics by journalists, political commentators and, occasionally, by TM's fellow party members. Similarly, the tautology is sometimes used as a sort of defensive reply to criticism.

Journalists and political commentators often do genuinely request for clarification. This is the case of the British political commentator and TV presenter Andrew Marr during an interview with TM, where he even uses a euphemism for Brexit (i.e. the B-word):

(14) Andrew Marr (4 September 2016, on BBC One The Andrew Marr Show).

'Now, you've already mentioned the B-word, so let's talk about Brexit. 'Brexit means Brexit,' you said, but what does Brexit mean?"

Other examples are found at a G20 press conference in China where TM tries to clarify that $B m B$ implies respecting the public mandate when asked by two journalists to be more specific, as in examples (15)-(16) (see Appendix). Further examples are provided by Deputy Political Editor with The Guardian Rowena Mason, Baroness Patience Wheatcroft, a peer in the House of Lords, and Jonathan Pie, a fictitious British news reporter, created and played by British actor and comedian Tom Walker, in a video clip uploaded to Youtube where he rants about the state of UK politics. These are detailed in examples (17)-(19) in the Appendix.

While journalists and political commentators often simply wish their interlocutors to clarify what they mean, requests by politicians can also be less neutral. An example is found in a parliamentary exchange between Conservative MP Sir Edward Leigh (EL) and TM. Although Leigh himself does not use the tautology explicitly, he paraphrases it by saying "We're leaving the EU" followed by "we're going to make a success of it" as in many of the examples referred to above. Then, he spells out his idea of Brexit (no single market, free trade deal) and asks TM to clarify what hers is.

(20) Edward Leigh, Theresa May (20 July 2016, at PM's Questions in the House of Commons).

EL: "I agree with the PM [cheers and laughter]. We're leaving the EU and we're going to make a success of it. So will the PM make my day special by saying she is prepared to reject staying in the single regulated market and offering instead to our friends in Europe a free trade deal, very much in their interest? Let's take back control."

TM: “... My Honourable friend just made my day... [a]nd can I assure him as we look at the results of the referendum I'm very clear Brexit does mean Brexit. As he says, we will make a success of it. What we need to do in negotiating the deal is to ensure that we listen to what people have said about the need for controls on free movement. But we also negotiate the right deal, and the best deal, of trade in goods and services for the British people."

Leigh wants to make sure that TM has the same idea of Brexit as his. Going a step further, another of TM's party members, Boris Johnson, takes advantage of lack of clarity to 'fill' the apparent 'vacuum' in the $B m B$ tautology pointed out by Rowena 
Mason - example (17) in the Appendix - when she claimed that "one of the problems Theresa May's got with this phrase 'Brexit means Brexit' is that that doesn't really mean anything at all and she's not explaining what she wants and so it's left this vacuum for other people to fill it...". In the absence of a clear blueprint, Johnson, a leading public face in the Vote Leave campaign and member of the Change Britain Pro-Brexit group, interprets the $B m B$ in what would later come to be known as a 'hard Brexit' fashion.

(21) Boris Johnson (Broadcast on September 2016, ad of the Change Britain group).

"Brexit means Brexit and that means delivering on their instructions and restoring UK control over our laws, borders, money, and trade."

Moreover, in this second phase, $B m B$ is also used both by Brexiteers and remainers to criticize and/or attack TM. $B m B$ is used, for example, to criticize her apparent lack of plan or action as well as to criticize the Government's perceived potential untrustworthiness. In this specific case, the OBJECTION ICM materialises in an actual CRITICISM ICM. Criticism has been considered as a speech act (e.g. Min 2008). In the current analysis, criticism is considered as an ICM that implies a CRITICIZER who gives harsh judgments or finds fault with the ideas or actions of a CRITICIZEE.

Criticisms for the perceived lack of ideas, plan, or action can be seen in the use of $B m B$ by two Scottish nationalist politicians, Nicola Sturgeon, First Minister of Scotland, and Stewart Hosie, an SNP MP who voted Remain. Sturgeon accuses TM of not having a Brexit plan, as can be seen in example (22) in the Appendix. Hosie claims that TM doesn't know what Brexit means herself. For both Scottish nationalists, $B m B$ is only a "meaningless campaigning expression" (Hosie) or "just a soundbite" (Sturgeon). The example below is from Hosie:

(23) Stewart Hosie (14 September 2016, parliamentary exchange between Charlie Elphicke and Hosie).

"...the hon. Gentleman made a pitch to leave now because, he said, "Brexit means Brexit and we will make a success of it"; I think I am quoting accurately. The problem... is that when the PM - the leader of Government, the high held yin of the Tory party - is asked, "If Brexit means Brexit, does it mean we will be staying in the single market?", she does not know... So on the basis that "Brexit means Brexit" is no more than a meaningless campaigning expression..."

As for Labour Party members, an interesting example of $B m B$ is found in an exchange between opposition leader Jeremy Corbyn (JC) and TM in the autumn of 2016. In this exchange, Corbyn mocks TM's use of the tautology immediately after she seems to have refrained herself from saying it. Corbyn seems to take $B m B$ at face value, suggesting it is uninformative. Recognizing Corbyn's sarcastic comments, May indicates how the tautology should be interpreted in her view.

(24) Theresa May, Jeremy Corbyn (28 October 2016, House of Commons).

TM: "In relation to the issue of clarity, on the aims that the Government has in relation to Brexit, I have been very clear and I will be very clear again. The... (general noise)..." 
JC: "I thought for a moment the PM was going to say Brexit means Brexit again ((laughter) $) \ldots$ there are others... ((general noise)) ((Corbyn gestures to PM)) I'm sure (.) I'm sure she'll tell us one day what it actually means...".

TM: "...the leader of the opposition tries to poke fun at the phrase of Brexit means Brexit but the whole point is this (general noise)... it's this government that is listening to the voice of the British people (cheers of approval)... Brexit means Brexit and that means we're coming out of the European Union ((general noise)) what the Rt Hon gentleman tries to be doing is frustrating the will of the British people (cheers of approval) by saying that Brexit means something completely different."

Further examples of the use of $B m B$ to criticize the Government are found in a political debate on TV where Labour MP Stella Creasy, who participates alongside Conservative MP Ian Duncan Smith, criticizes the Government for their reluctant attitude to act in parliament, as expressed in example (25) (see Appendix). Another example of $B m B$ used to criticize the lack of a plan or action comes from another of TM's political opponents, remainer Nick Clegg, leader of the Liberal Democrats, at the party's autumn conference 2016 :

(26) Nick Clegg (19 September 2016, Autumn Liberal Democrat conference, Brighton).

"'Brexit means Brexit' - have you ever heard a more inane and disingenuous phrase in modern British political discourse?... It is used, of course, robotically by Theresa May to cover up, to camouflage the indignity of the paralysis at the heart of this Conservative government... paralysis because of the tension between their wish to trim freedom of movement and their wish to have access to the single market."

Clegg's criticism points to an important conceptual development in relation to the meaning of Brexit. In the FACTUAL BREXIT ICM outlined above, Brexit is an actual event to happen in the not-too-distant future after the 2016 referendum. Yet the actual form of Brexit was unknown at the time. As Schnapper (2018) puts it, “...the process and practicalities of actually leaving the organisation... as well as the type of relations between the UK and the EU in the future were never discussed. Theresa May faced a blank sheet with no precedent to refer to" (p. 21). As political negotiations and public discussion ensued on that form of Brexit, two clear Brexit-related ICMs seem to have taken shape, even leading to specific compound nouns capturing their content: soft Brexit and hard Brexit (Schnapper 2018 for an account). These are sketched as follows:

SOFT BREXIT ICM.

After Brexit, the UK will still be closely aligned with the EU and special access to the single market. This implies, in return, compromise on immigration agreements but this is acceptable. Brexit will minimise the impact on trade and businesses by essentially staying in the customs union.
HARD BREXIT ICM

After Brexit, the UK will be completely out of the EU, including both the single market and the customs union. The UK will fall under the WTO rules and it will have full control over its borders and immigration. The possible short-term disruption that Brexit may cause is acceptable. 
These additional ICMs can be considered to be at the heart of criticisms of TM's Government's perceived untrustworthiness, as seen in several exchanges in the months before the Withdrawal Agreement was released and agreed upon by the UK's Government and the EU (November 2018). Former UKIP leader Nigel Farage, a prominent supporter of the Vote Leave campaign, had brought up TM's previous support of the Remain option in the 2016 referendum in an interview in July 2016 where he claimed that it was ironic that a remainer, upon becoming the new PM, had coined and used the tautology, as seen in example (27) in the Appendix. Yet Farage's criticism becomes bitterer in a further interview in 2017 example (28) in the Appendix - and especially in 2018, where he not only shows distrust but also criticizes the Government for lack of action after the UK 2017 snap election and for TM's version of Brexit leading to the Withdrawal Agreement later that year.

(29) Nigel Farage (11 July 2018, interview on Fox News).

“...now, what Mrs. May has done is, frankly, to behave totally dishonestly with the British public. She told us 'Brexit means Brexit'. We will take back control of our laws, our borders, and our money, and the compromise that she put forward at Chequers last week, the PM's country home, frankly was a betrayal of those things."

Farage's comment also points to the two Brexit ICMs discussed above, that is, a SOFT BREXIT ICM and a HARD BREXIT ICM. The second nominal in the tautology, in this case, is understood as referring to an eventual 'soft Brexit' (i.e. 'Brexit means soft Brexit') while he holds a view of Brexit more in line with a 'hard Brexit' (i.e. 'Brexit means hard Brexit'). This interpretation can also be seen in an exchange between TM and Tory MP Sir Desmond Swayne in the House of Commons as well as in a political comment by Tory MP Priti Patel in a TV interview conducted by Adam Bolton in which she criticizes TM's deal and considers it to amount to some sort of soft Brexit. These instances of $B m B$ are found in examples (30) and (31), respectively, in the Appendix.

What we see in these examples is something akin to Fillmore's (1982) notion of 'frame conflict', which is often the source of misunderstandings in language use leading, at times, to criticism, irony or even communication breakdown. The Brexit ICMs conflict is explicit in an instance of very hard criticism by Nigel Farage on discussing the Withdrawal agreement that is, for him, that of a SOFT BREXIT ICM:

(32) Nigel Farage (15 November 2018 on LBC radio).

"When will we end free movement?... when will be able to make our own laws? Well, it looks like 2030 is now the date that's been decided on the sum of it, and why should that change for all the rest of it. I simply cannot believe we have got a PM who stands up and says Brexit means Brexit, but what she really means is Brexit means Remain. I'm absolutely... I'm so angry at that I can barely put it into words..."

Farage interprets Brexit under the HARD BREXIT ICM and he equates TM's tautology with the meaning, essentially, of remaining somehow tied to the EU. The same interpretation is found in an exchange between TM and Conservative MP Andrea 
Jenkyns (AJ), herself an advocate for the Leave Means Leave group, in the summer of 2018. For her, the terms of the UK-EU negotiations were either leading to a soft Brexit or no Brexit at all (i.e. some sort of 'Remain') when she asked TM to inform the MPs in the House of Commons at what point it was decided that "Brexit means Remain" - example (33) in the Appendix. TM replied that "at absolutely no point... because Brexit continues to mean Brexit". Her reply is another example of some sort of 'defensive' use of the $B m B$ tautology. A similar use is found in another exchange between TV presenter Evan Davis (ED), and Tory MP David Jones (DJ). Evan Davis suggested that many people had voted for Labour and not for Conservative TM because they disliked her version of Brexit. Davis Jones simply replied by saying "Brexit, actually, to coin a phrase, does mean Brexit. We have already set ourselves on the course for leaving the European Union." The example is found in (34) in the Appendix.

Attacks such as the ones referred to above may explain why TM and her collaborators eventually ceased to use the tautology regularly. Moreover, as mentioned above, TM was eventually unable to pass her Brexit deal and ended up resigning as party leader and PM. With a new hard-line Brexiter PM in office, Boris Johnson, from July 2019 on, the HARD BREXIT ICM seems to have evolved into a NO DEAL BREXIT ICM. Limitations of space prevent further discussion but that ICM seems to encapsulate the idea among Brexiters that "no deal is better than a bad deal", as expressed by Priti Patel in example (31) in the Appendix.

\subsubsection{Form}

The formal aspect of constructions involves various components out of which special attention is paid here to the syntactic, phonetic-phonological, and gestural aspects of the $B m B$ construction. Moreover, the analysis indicates various form/meaning-use interactions.

\section{Syntactic-grammatical form}

$B m B$ is a nominal or equative tautology in which the elements joined by a verb form are nouns (e.g. work is work), noun phrases (e.g. a job is a job) or even nominalized adjectives/adverbs (e.g. big is big). ${ }^{3}$ The tense of the verb mean in BmB is the same as that of many nominal tautologies, that is, the present simple in the singular (i.e. is) or plural (i.e. are) forms. Yet some nominal tautologies use the future tense, as in boys will be boys.

A relevant formal aspect of the $B m B$ construction is why the future tense is not used. In this respect, there is some evidence that the syntactic form of tautologies seems to influence the meaning and interpretability of tautological expressions (Wierzbicka 1987). In an experimental study, Gibbs and McCarrell (1990) found that experimental participants regarded the combination of modal, future tense forms with human role nouns (e.g. teachers will be teachers) as more acceptable, versus modal, future tense forms combined with concrete nouns (e.g. carrots will be carrots), which were considered the least acceptable. Gibbs and McCarrell explain their

3 See Meibauer (2008), Rhodes (2009) and Ward and Hirschberg (1991) for other syntactic forms of tautologies in English. 
findings suggesting that the more entrenched stereotypes are about a given noun, the easier it is to interpret a tautology. Thus, language users typically have clearer stereotypes about human groups and human activities (e.g. friends, war, etc.) than about human objects (e.g. carrots). Thus, while a stereotype of friends is their supportiveness and of war, its collateral damage, stereotypes are less clear for concrete nouns referring to objects such as carrots.

Of particular relevance here are Gibbs and McCarrell's results regarding abstract nouns with present simple (e.g. promises are promises) and modal, future tense forms (e.g. war will be war). The researchers found that abstract nouns, particularly in the singular, were easier to understand with present simple forms than with future tense forms. Given these results, a tautology such as war is war would be easier to interpret than war will be war. If this is the case, Brexit means Brexit is a more easily interpretable tautology than Brexit will mean Brexit, which was not found at the data-gathering phase of the study. Yet in Gibbs and McCarrell's study, abstract nouns with a modal future tense were also relatively well understood, so their abstractness cannot be the single reason why the verb in $\mathrm{BmB}$ is in the present simple. It is suggested here that the present simple is preferable to a future form given the ACCEPTANCE ICM evoked in the use of the tautology in the context of the situation after the 2016 referendum: TM wanted the general public and opponents to accept the new situation quickly so that they could 'move on' to another stage of the Brexit process. A tautology such as Brexit will mean Brexit would, therefore, be inappropriate. The future tense form seems to predicate "continued existence" (Gibbs and McCarrell 1990 , p. 139) but this would seem to foresee a future scenario in which Brexit will still happen - not having been carried out, accepted or unquestioned in the short term. This is exactly the opposite of the ACCEPTANCE ICM.

Further interaction of form and meanings or context of situation can be seen in the syntactic variations of the $B m B$ construction. Thus, when the ACCEPTANCE ICM is evoked in the use of the tautology, the syntactic form of the tautology is the default one (i.e. Brexit means Brexit), as in TM's first use (see example (2) above). However, when the OBJECTION FRAME underlies the use of $B m B$ some instances of it are reinforced by the use of the emphatic stand-in auxiliary $d o$ and, occasionally, indeed, as in example (35). Examples (36)-(38) in the Appendix further illustrate this syntactic variation.

(35) Theresa May (5 September 2016, at a G20 press conference with Barack Obama, Hangzhou, China).

"One of the questions you asked me about Brexit - yes, Brexit does indeed mean Brexit. On the $23^{\text {rd }}$ of June, the people in the UK voted for the UK to leave the European Union..."

In these examples, the OBJECTION FRAME motivates syntactic variation in the use of $B m B$ as a reply by an ACCEPTOR to the objections or criticisms of an ACCEPTEE, to use terms for the participants in the ACCEPTANCE ICM discussed above. Moreover, the ACCEPTEE's interpretation of $B m B$ as mediated by the SOFT BREXIT ICM results in yet further variation on the tautology, although of a lexical type: Brexit means Remain, as seen in examples (32)-(33) in the Appendix. This variant also prompts another syntactic variation on $B m B$ using a verbal periphrasis Brexit continues to mean Brex$i t$, as in example (39), as a reply to criticism from an ACCEPTEE. 
(39) Andrea Jenkins, Theresa May (18 July 2018, at PMQs in a House of Commons).

AJ: "Can the PM inform the house, at what point it was decided that Brexit means Remain? ((groans))."

TM: "Can I... can I say to my Honourable friend: at absolutely no point. Because Brexit continues to mean Brexit ((cheers))."

Finally, another lexico-grammatical variation of $\mathrm{BmB}$ motivated by the ICMs conflict can be seen in the (very) occasional use of is instead of means as the copula verb in the construction. This suggests that no clarification is necessary as originally implied by the use of mean. Instead, simple acceptance of the HARD BREXIT ICM is demanded (as opposed to a SOFT BREXIT ICM). This can be seen in a stinging attack by an audience member (AM) on a TV debate programme as a response to Tory MP Justine Greening (JG), who had just defended her support for a 'soft' version of Brexit.

(40) Justine Greening, audience member (1 February 2018, BBC One Question time).

JG: “...what I'm saying, sir, is that if we want to actually get a sustainable Brexit, then we're going to have to have some give-and-take and we're gonna have to find a way of approaching Brexit that, genuinely, can bring..."

AM: "You're characterising Brexiteers as extreme. Brexit is Brexit. It's not difficult to understand. It's Brexit. Don't tell us... I'm fed up of hearing this from politicians; don't tell us that those 'ardent Brexiteers'... we just want Brexit. It means getting out of the single market, governing ourselves, controlling our borders. This is not rocket science, it's called Brexit."

\section{Phonetic-phonological form}

What the syntactic variations discussed above seem to point at is especially relevant and significant: how the evolving context of situation and use have an impact on linguistic form. This can also be seen at the phonetic-phonological level of the $\mathrm{BmB}$ construction. This level can be described simply in terms of a classic detemporalized phonemic segmental representation: /breksit mi:nz breksit/, with variation in the stop-fricative cluster in Brexit (i.e. /ks/ or /gz/). Phonemes are certainly one level at which the formal component of constructions can be characterized (Mompean 2006, 2014 for discussion). Yet suprasegmental aspects are also relevant. The pitch accent structure of the $B m B$ construction, for example, can be described as $\mathrm{H}^{*} \mathrm{H}^{*} \mathrm{H}^{*} \mathrm{~L}-\mathrm{L} \%$ in ToBI-based notation. This notation indicates that $\mathrm{BmB}$ begins, as is often the case in the corpus, with a high pitch accent and finishes with another high pitch accent, falling steadily to a low. ${ }^{4}$ This is, at least, the pattern most frequently found when

4 In ToBI, one of the standard and most influential systems of notation for transcribing and annotating prosody (see e.g. Beckman, Hirschberg, and Shattuck-Hufnagel 2005), individual syllables are tagged with either low (L) or high $(\mathrm{H})$ symbols. Accents are distinguished by appending a star (*) so, for example, $\mathrm{H}^{*}$ refers to a high pitch accent and $\mathrm{L}^{*}$ to a low pitch accent. Phrase and boundary tones are distinguished by appending either a minus sign (-) or a percentage sign (\%) such as L\% (final low boundary tone) or $\mathrm{H} \%$ (final high boundary tone). Moreover, prosodic boundaries are annotated by means of a break index in which each boundary is tagged with a number ranging from 0 to 4: 0 (clitic group boundary), 1 (word boundary), 2 (boundary with no tonal mark), 3 (intermediate phrase boundary) and 4 (intonation phrase boundary). 
$B m B$ is used as a self-contained, main clause (see Figure 1). Yet when $B m B$ is embedded in a subordinating clause, particularly, when it's not utterance-finally, it can have other types of pitch accent (e.g. low rise).

While these phonological aspects of the $B m B$ construction are important, some relevant discourse-based aspects of the construction related to its prosody and use of some phonetic features are also especially interesting. One such aspect is the rhythmic structure of the construction as well as the local tempo of the items in the construction used in context. The $B m B$ construction, for example, can be parsed into five syllables. These syllables can be grouped into a two- or a three-foot rhythmic template. In the first case, the verb means is accented in the second foot of a threefoot rhythmic template starting and ending with a trochee (i.e. $\left.\left.|' \sigma \sigma|^{\prime} \sigma\right|^{\prime} \sigma \sigma \mid\right)$. In the second case, the verb means is de-accented and included at the end of a tertiary foot in a two-feet (dactyl+trochee) prosodic template (i.e. |' $\sigma \sigma \sigma|' \sigma \sigma|)$. An example of the three-foot rhythmic template can be found in TM's first use of the tautology on 30 May 2016 (Figure 1) while an example of the two-foot rhythmic template is found in political commentator Rowena Mason on 11 September 2016 (Figure 2).

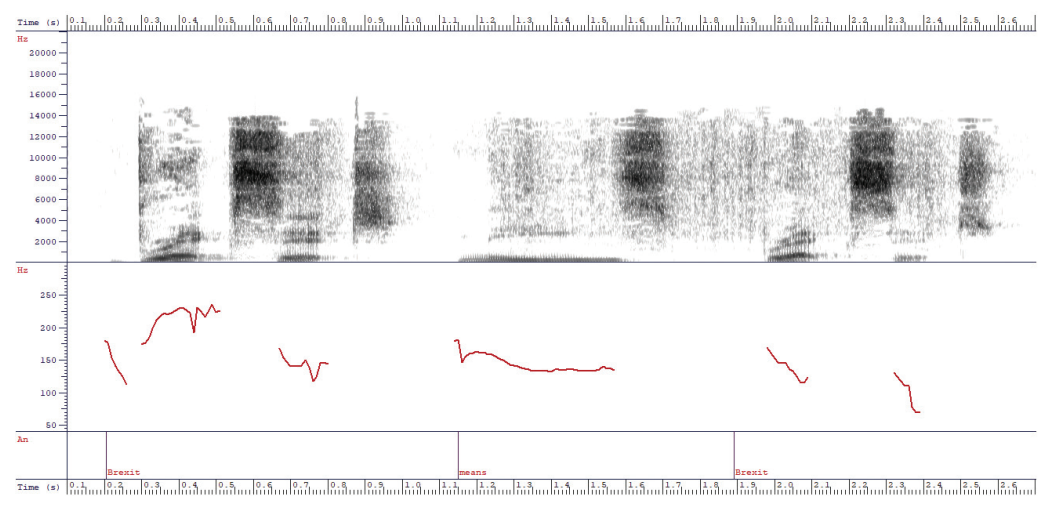

Figure 1. Spectrogram and pitch track of Brexit means Brexit by Theresa May on 30 June 2016, in a speech announcing her leadership candidacy.

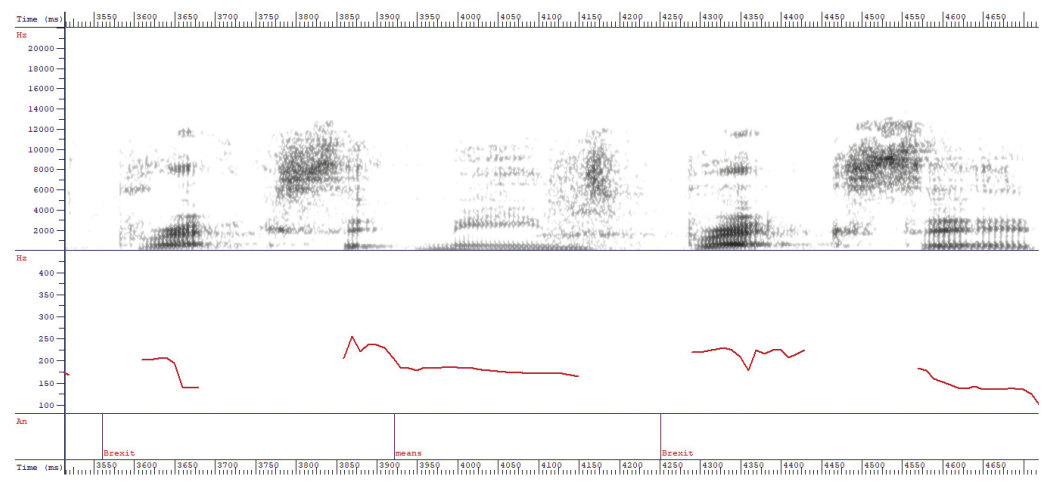

Figure 2. Spectrogram and pitch track of Brexit means Brexit by Rowena Mason on 11 September 2016 on Sky News Murnaghan. 
The use of either of these two templates seems to be partly determined by the activation of one of the two ICMs discussed above, that is, the ACCEPTANCE ICM or the OPPOSITION ICM as well as by, in the case of the ACCEPTANCE ICM, other contextual factors such as the perceived stronger or weaker presence of an audience of potential acceptees. Thus, if acceptance is consciously sought for, a three-foot rhythmic template is also accompanied by a longer duration of the construction. In these cases, focused information is highlighted by prosodic accents, which explains why each instance of Brexit in the construction is accented, but also why mean also is, since the tautology can be interpreted, as already advanced before, as a command to make no mistake about the meaning of Brexit as well as to accept its inevitability, which can be paraphrased as 'you have to accept that the meaning of Brexit is that the UK will inevitably leave the EU'. This is the case of TM's first uses of the tautology at key political moments for her such as her speech announcing her leadership candidacy in London in June 2016 or her first speeches as Tory leader on 11 July, as seen in examples (41)-(43) in the Appendix. Her use of the tautology outside the Houses of Parliament is reproduced here for convenience:

(43) Theresa May (11 July 2016, first speech as Tory leader, outside the Houses of Parliament).

"Brexit means Brexit and we are going to make a success of it."

The duration of the $B m B$ tautology in these cases is relatively long, respectively, 2.52 ms., $2.48 \mathrm{~ms}$., and $1.95 \mathrm{~ms}$. In the three cases, $B m B$ is used to make the audience accept the result of the referendum. In this attempt, TM also uses phonetic features such as aspiration in the release of the /t/ of Brexit, which is often considered to be emphatic when it appears word-finally (Mompean 2004). In contrast, a two-foot rhythmic structure is used when journalists or political commentators request for clarification or comment on the lack of clarity regarding the meaning of $B m B$. This can be seen in the use of a $B m B$ by a journalist at a G20 joint press conference by TM and Barack Obama or in a comment by Rowena Mason on a Sky News politics programme, corresponding to examples (44) and (45), respectively, in the Appendix. The two-foot rhythmic structure is also used by politicians and political commentators when attacking TM and her Government, as can be seen in example (46) in the Appendix by Jeremy Corbyn or example (47), reproduced below, by political commentator Jonathan Pie [Tom Walker].

(47) Jonathan Pie [Tom Walker] (30 October 2016, Youtube).

"Okay, Brexit means Brexit but I want to know what it means. I want the details, and Theresa May, she's saying nothing."

These cases of the $B m B$ tautology are shorter: $1.25 \mathrm{~ms} ., 1.22 \mathrm{~ms} ., 140 \mathrm{~ms} .$, and 1.00 ms., respectively. Moreover, they typically lack aspiration. In many cases, such as (45) by Rowena Mason - see Figure 2 above - the whole utterance shows less overall intensity and lower $f_{0}$, as well as the use of glottalisation (creaky voice) at the end of the two instances of Brexit instead of a stop release for $/ \mathrm{t} /$, which also prevents aspiration.

It should also be pointed out that the very activation of the ACCEPTANCE ICM does not imply, however, that a given utterance of the tautology will necessarily be longer than when it is merely 'quoted' to question and/or criticize. Repeated use of the tau- 
tology also leads to further entrenchment and, apparently, phonetic reduction, as has repeatedly been documented in the literature (see for example Bybee 2006). This can even be seen in the use of the tautology by TM's collaborators - and herself at times - when it activates the ACCEPTANCE ICM but has become a routine mantra. Moreover, contextual factors such as the perceived stronger or weaker presence of an audience of potential acceptees may also play a role in the use of a shorter, two-foot rhythmic template. This happens, for example, in TM's use of $B m B$ during a cabinet meeting on 31 August 2016. TM is surrounded by cabinet members, who have already accepted her leadership and the UK's eventual withdrawal from the EU (see figure 3). She then uses $B m B$ more as a reminder of policy than as an instrument to demand acceptance. The duration of the tautology on that occasion is $142 \mathrm{~ms}$.

(48) Theresa May (31 August 2016, at a cabinet meeting, London).

"We must continue to be very clear that Brexit means Brexit, that we're going to make a success of it."

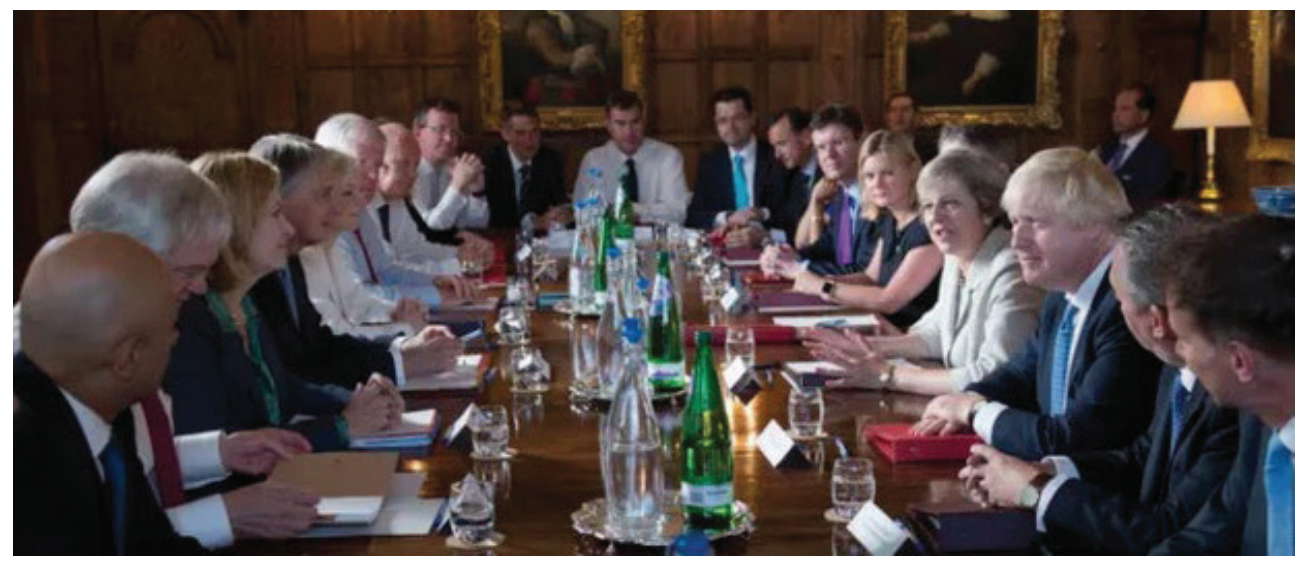

Figure 3. Theresa May at a cabinet meeting on 31 August 2016.

\section{Gestural form}

Gesticulation is an integral part of language use in spoken interactions so it is unsurprising that it can be seen at play in almost every instance of $B m B$ in the corpus. Although a detailed analysis of the gesticulation parameters associated with this construction is beyond the scope of this paper, there are very clear patterns that greatly help its description. In our corpus, the main type of gestures associated with the $\mathrm{BmB}$ construction is 'beat' gestures. These are typically hand (and/or head) movements that emphasize the spoken discourse itself with up-and-down or back-and-forth movements. Beats are often referred to as 'emphatic gestures' as they create emphasis and grab attention, and are closely related to - and sometimes overlap with - rhythmic aspects of speech (e.g. prosodic accents). Other main functions of beat gestures are focus marking (e.g. introducing a new topic in speech) and discourse structure marking (e.g. summarizing an action) (e.g. Alibali et al. 2001; Dimitrova et al. 2016; Lucero, Zaharchuk and Casasanto 2014; McNeill 1992; Shattuck-Hufnagel et al. 2016). 
The typical beat gesticulation associated with the $B m B$ tautology correlates perfectly with the other associated features of the two versions of the tautology (acceptance vs opposition). In our corpus, forceful and especially emphatic beat gestures are most often realized with two hands, though other possibilities, such as the use of a single hand or an index finger have also been found. In this sense, the beat gestures observed very clearly accentuate the two prosodic rhythms described above. This emphasis strongly suggests that the rhythmic structure plays a fundamental role in the formal make-up of the construction, as well as in distinguishing between both readings. In the corpus, a three-foot rhythmic template is typically associated with a three-beat gesture, as exemplified by TM on 11 July 2016 in her first speech as Tory leader outside the Houses of Parliament (see Figure 4):

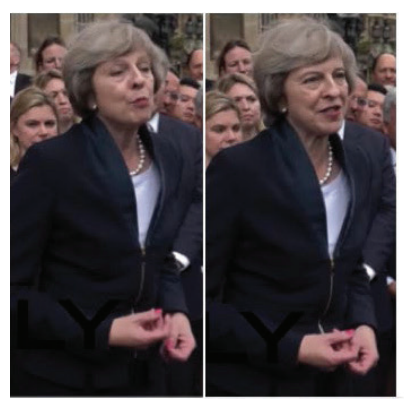

Brexit

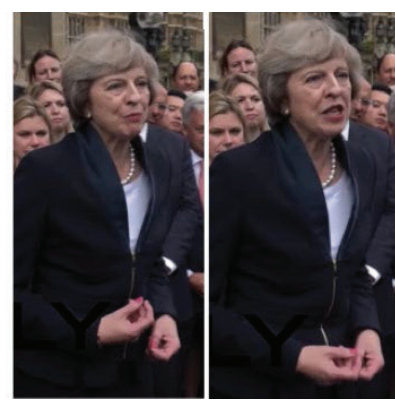

means

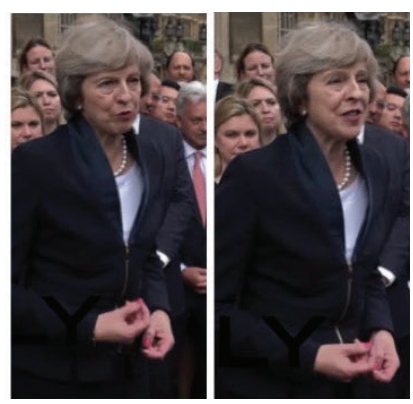

Brexit

Figure 4. Three-beat gestures by Theresa May while uttering Brexit means Brexit (11 July 2016, first speech as Tory leader, outside the Houses of Parliament). The two sequences of each beat are shown side by side.

In contrast, a two-foot rhythmic template is typically associated with a two-beat gesture, as exemplified by Stella Creasy on a TV programme while criticizing the Government for their reluctant attitude to act in parliament regarding Brexit as of early 2017 (Figure 5).

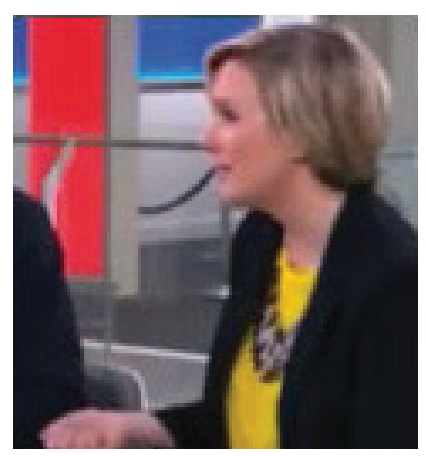

Brexit

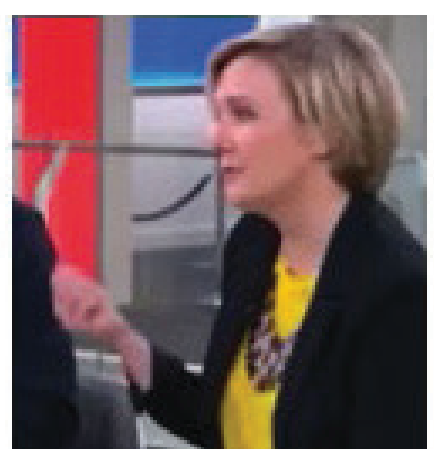

means

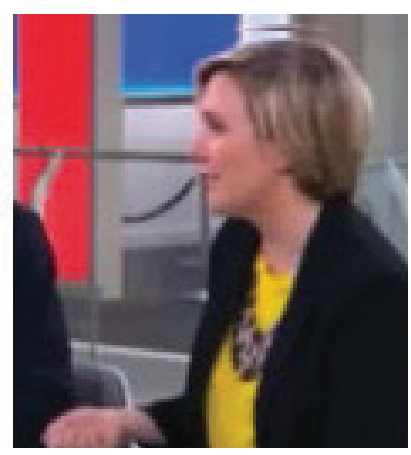

Brexit

Figure 5. Two-beat gestures by Stella Creasy while uttering Brexit means Brexit (5 February 2017, on Sky's Sophie Ridge on Sunday). 
There have been other features found in the gesticulation of the utterance, though the small number of the corpus offers only hints; however, they are interesting and intriguing enough to merit their mention here. The feature we are referring to is a certain lateralization found while uttering the tautology. In the cases we have been able to analyze, this lateralization reveals itself in head-movements (sometimes associated with gaze direction changes) and hand motions as well. We found a right-toleft lateral direction in almost every case, as illustrated in Figure 6, which seems to contradict the usual direction found in lateralization (Pagán-Cánovas and Valenzuela 2017).

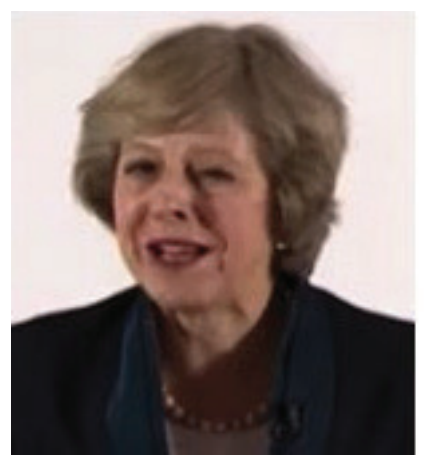

Brexit

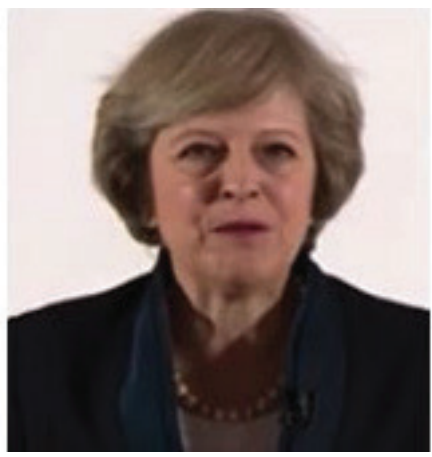

means

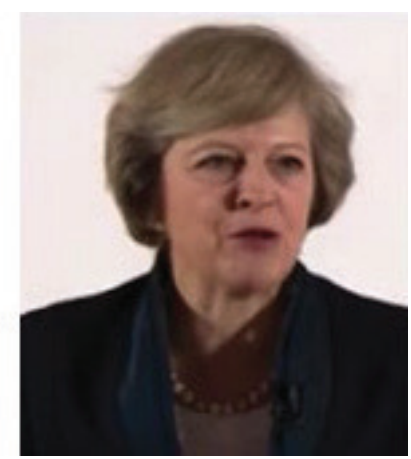

Brexit

Figure 6. Right-to-left direction of head-movement gesture by TM (11 July 2016, speech at the Conservative Party conference, Birmingham).

It is well-known that time flows from left to right in English (Santiago et al. 2007), a fact which has been associated with the direction of reading (Casasanto and Bottini 2014); numerical magnitude also follows a left-to-right lateral line (Dehaene, Bossini and Hiraux 1993). One possible explanation refers to the role of agency: Mass et al (2009) found that Italian speakers placed elements perceived socially as stronger and more agentive at the right. In the few lateral uses found, the right-to-left direction has been found with the ACCEPTANCE ICM reading, in which the second element (the second Brexit) provides the stronger and more central prototypical meaning (cf. Section 3.4.1). Though this is just a hint, it is interesting enough to elicit further search of lateralization effects in other tautological units with a similar structure, which would confirm this 'direction towards the prototype' possibility.

\subsubsection{Summary}

The analysis of the $B m B$ tautology above reveals two main patterns of use with somewhat different meaning and formal features. Table 1 summarises some of the (proto)typical features of these patterns, although variation exists in the corpus as is the case with most - if not all - linguistic phenomena. As a case in point, while aspiration of /t/ in Brexit and a three-foot rhythmic is typical of uses of $B m B$ activating an ACCEPTANCE ICM, progressive entrenchment - leading to phonetic reduction - and contextual features such as the perceived weaker presence of an audience of poten- 
tial acceptees may lead to two-foot $B m B$ deliveries. Reading also often prevents beat gestures. Conversely, emphatic use of $B m B$ with an underlying OPPOSITION ICM is found in the corpus with features of the more emphatic, acceptance-seeking pattern.

Table 1. (Proto)typical features of the two patterns of use of $B m B$ identified in the corpus.

\begin{tabular}{|c|c|c|c|c|}
\hline & USER & SEMANTIC & & FORMAL \\
\hline \multirow[t]{3}{*}{ PATTERN 1} & \multirow[t]{3}{*}{$\begin{array}{l}\text { Theresa May } \\
\text { and supporters }\end{array}$} & \multirow{3}{*}{$\begin{array}{l}\text { CATEGORY FOR SALIENT } \\
\text { PROPERTY } \\
\text { FACTUAL BREXIT ICM } \\
\text { ACCEPTANCE ICM }\end{array}$} & Synt.: & $\begin{array}{l}\text { BmB and variations } \\
\text { (e.g. } B \text { does mean } B \text { ) }\end{array}$ \\
\hline & & & Phon.: & $\begin{array}{l}\text { 3-foot rhythmic template } \\
\text { long duration } \\
\text { emphatic aspiration }\end{array}$ \\
\hline & & & Gest.: & $\begin{array}{l}\text { 3-beat gestures } \\
\text { (or no beats) }\end{array}$ \\
\hline \multirow[t]{3}{*}{ PATTERN 2} & \multirow{3}{*}{$\begin{array}{l}\text { Commentators } \\
\text { and critics }\end{array}$} & \multirow{3}{*}{$\begin{array}{l}\text { CATEGORY FOR SALIENT } \\
\text { PROPERTY } \\
\text { FACTUAL BREXIT ICM } \\
\text { OPPOSITION ICM } \\
\text { (HARD BREXIT ICM) }\end{array}$} & Synt.: & $B m B$ (no variation) \\
\hline & & & Phon.: & $\begin{array}{l}\text { 2-foot rhythmic template } \\
\text { short duration } \\
\text { no aspiration }\end{array}$ \\
\hline & & & Gest.: & $\begin{array}{l}\text { 2-beat gestures } \\
\text { (or no beats) }\end{array}$ \\
\hline
\end{tabular}

What the analysis reveals, in any case, is how different semantic-pragmatic uses have an impact on the linguistic form (e.g. prosody, gesture) and how fluid the interaction is between linguistic meaning/form and the social and cultural context in which language is used.

\section{Conclusion}

This paper has analysed the Brexit means Brexit tautology from a constructionist perspective, using a corpus-assisted discourse analysis approach. The analysis has shown how a basic ICM underlies and motivates the use of the tautology and how social changes in perception of that ICM create two opposing versions (which we have called the ACCEPTANCE ICM and the OPPOSITION ICM), connected in turn to two main patterns of use. More specifically, the analysis has pointed out how the semantic and pragmatic components of the tautology are grounded in the political context and the opposing ICMs emerge at different times: the original one is found shortly after the 2016 referendum on the UK's membership of the EU (and its prime example is Theresa May's use of the phrase on 30 June 2016), while the alternative version, related to a more critical view of Theresa May, was developed in the months following. The paper thus shows the fluid interaction between social features and linguistic forms, revealing how language and social factors are inextricably related, and explanations of language use cannot eschew the role of social paraments. Finally, the analysis pro- 
vided has shown the usefulness of the inclusion of aspects such as rhythm, prosody, and gesticulation in the formal characterization of constructions. This effectively points out how the new multimodal turn in construction grammar seems indeed to be a path worth taking, which may offer more balanced and nuanced descriptions of language use.

\section{References}

Alibali, Martha W., Dana C. Heath, and Heather J. Myers (2001). Effects of visibility between speaker and listener on gesture production: Some gestures are meant to be seen. Journal of Memory and Language 44.2: 169-188.

Autenrieth, Tanja (1997) Tautologien sind Tautologien. In Eckard Rolf (ed.), Pragmatik. Implikaturen und Sprechakte [Linguistische Berichte, Sonderherft 8] (pp. 12-32) Opladen: Westdeutscher Verlag.

Baker, Paul (2006). Using Corpora in Discourse Analysis. London: Continuum.

Beckman, Mary E., Julia Hirschberg, and Stefanie Shattuck-Hufnagel (2005). The original ToBI system and the evolution of the ToBI framework. In Sun-Ah Jun (ed.) Prosodic Typology: The Phonology of Intonation and Phrasing (pp. 9-54). Oxford: Oxford University Press.

Blitz, James (2016, December 20). Year in a word: Brexit. Financial Times. Retrieved from https://www.ft.com/content/2041e104-c394-11e6-9bca-2b93a6856354

Brown, Penelope and Stephen Levinson (1987). Politeness: Some Universals in Language Use. Cambridge: Cambridge University Press.

Bybee, Joan L. (2006). From usage to grammar: The mind's response to repetition. Language 82(4): 711-733.

Casasanto, D. and R. Bottini (2014). Mirror-reading can reverse the flow of time. Journal of Experimental Psychology: General 143: 473-479.

Croft, William (2001). Radical Construction Grammar: Syntactic Theory in Typological Perspective. Oxford: Oxford University Press.

Csabi, Szilvia and Zoltán Kövecses (2014). Lexicography and cognitive linguistics. Revista Española de Lingüística Aplicada 27.1: 118-139.

Dawkins, Richard (1976). The Selfish Gene. Oxford: Oxford University Press.

Dehaene, S., Bossini, S \& Hiraux, P. (1993). The mental representation of parity and numerical magnitude. Journal of Experimental Psychology: General 122.3: 371-396

del Campo, Nuria (2011). A constructional approach to the expression of illocutionary meaning: An analysis of constructions performing the speech acts of requesting and begging. RESLA 24: 43-60.

del Campo, Nuria (2013). Illocutionary Constructions in English: Cognitive Motivation and Linguistic Realization. Berlin, Germany: Peter Lang.

Dimitrova, Diana, Mingyuan Chu, Lin Wang, Asli Özyürek, and Peter Hagoort (2016). Beat that word: How listeners integrate beat gesture and focus in multimodal speech discourse. Journal of Cognitive Neuroscience 28.9: 1255-1269.

Emmet, Dorothy (1962). 'That's that': Or some uses of tautology. Philosophy 37: 15-24.

Farghal, Mohammed (1992). Colloquial Jordanian Arabic tautologies. Journal of Pragmatics 17.3: $223-240$.

Fillmore, Charles (1982). Frame semantics. In The Linguistic Society of Korea (eds), Linguistics in the Morning Calm (pp. 111-137). Seoul: Hanshin. 
Fontaine, Lise (2017). The early semantics of the neologism BREXIT: A lexicogrammatical approach. Functional Linguistics 4:6(1-15). DOI 10.1186/s40554-017-0040-X

Fraser, Bruce (1988). Motor oil is motor oil: An account of English nominal tautologies. Journal of Pragmatics 12.2: 215-220.

Fried, Mirjam (2015). Construction Grammar. In Tibor Kiss and Artemis Alexiadou (eds.), Syntax - Theory and Analysis. An International Handbook (pp. 974-1003). Berlin: Mouton de Gruyter.

Frost, Tom (2017). Review of Brexit: Sociological Responses, edited by William Outhwaite, London, Anthem Press, 2017, 224 pp. European Journal of Cultural and Political Sociology 4.4: 487-501.

Gamble, Andrew (2017). British politics after Brexit. Political Insight 8.1: 4-6.

Geeraerts, Dirk (2003). Cultural models of linguistic standardization. In René Dirven, Roslyn M. Frank, and Martin Pütz (eds), Cognitive Models in Language and Thought. Ideology, Metaphors and Meanings (pp. 25-68). Berlin/ New York: de Gruyter.

Geoghegan, Peter (2017, March 16). Brexit Means Brexit - but what does Brexit mean? Political Insight 8.1: 3.

Ghomeshi, Jila, Ray Jackendoff, Nicole Rosen and Kevin Russell (2004). Contrastive focus reduplication in English (the salad-salad paper). Natural Language \& Linguistic Theory 22.2: $307-357$.

Gibbs, Raymond W. (1994). Figurative thought and figurative language. In Morton Ann Gernsbacher (ed.), Handbook of Psycholinguistics (pp. 411-446). San Diego, CA: Academic Press.

Gibbs, Raymond W. and Nancy S. McCarrell (1990). Why boys will be boys and girls will be girls: Understanding colloquial tautologies. Journal of Psycholinguistic Research 19.2: 125-145.

Goddard, Cliff and Anna Wierzbicka (2004). Cultural scripts: What are they and what are they good for? Intercultural Pragmatics 1.2: 153-166.

Goldberg, Adele E. (1995). Constructions: A Construction Grammar Approach to Argument Structure. Chicago, IL: The University of Chicago Press.

Goldberg, Adele E. (2006). Constructions at Work: The Nature of Generalization in Language. Oxford: Oxford University Press.

Goldberg, Adele. E. (2013). Constructionist approaches. In Thomas Hoffmann and Graeme Trousdale (eds), The Oxford Handbook of Construction Grammar (pp. 15-31). Oxford: Oxford University Press.

Grice, H. P. (1975). Logic and conversation. In Peter Cole and Jerry L. Morgan (eds), Syntax and Semantics, Volume 3, Speech Acts (pp. 41-58). New York: Academic Press.

Holler, Judith and \& Stephen C. Levinson (2019). Multimodal language processing in human communication. Trends in Cognitive Sciences 23.8: 639-652.

Kendon, Adam (1980). Gesticulation and speech: Two aspects of the process of utterance. In M. R. Key (ed.), The Relation between Verbal and Nonverbal Communication (pp. 207-227). The Hague: Mouton.

Koller, Veronika, Susanne Kopf, and Marlene Miglbauer (eds), (2019). Discourses of Brexit. London: Routledge.

Kwon, Iksoo (2009). A tautology is a tautology: Specificity and categorization in nominal tautological constructions. In Iksoo Kwon, Hannah Pritchett and Justin Spence (eds), Proceedings of the Thirty-Fifth Annual Meeting of the Berkeley Linguistics Society: General Session and Parasession on Negation (pp. 211-222). Berkeley, CA: Berkeley Linguistics Society. 
Lakoff, George (1987). Women, Fire, and Dangerous Things: What Categories Reveal About the Mind. Chicago, IL: The University of Chicago Press.

Langacker, Ronald W. (1987). Foundations of Cognitive Grammar. Vol. I: Theoretical Prerequisites. Stanford, CA: Stanford University Press.

Lucero, Ché, Holly Zaharchuk, and Daniel Casasanto (2014). Beat gestures facilitate speech production. In P. Bello, M. Guarini, M. McShane and B. Scassellati (eds.), Proceedings of the 36th Annual Conference of the Cognitive Science Society (pp. 898-903). Austin, TX: Cognitive Science Society.

Mardell, Mark (2016, July 16). What does 'Brexit means Brexit' mean? BBC News. Retrieved from https://www.bbc.com/news/uk-politics-36782922

Marmaridou, Sophia S. A. (2000). Pragmatic Meaning and Cognition [Pragmatics \& Beyond New Series 72]. Amsterdam: John Benjamins Publishing Company.

Martin, Mike W. (2013). Of Mottos and Morals: Simple Words for Complex Virtues. Plymouth: Rowman \& Littlefield.

Mass, A. Suitner, C. Favaretto, X. \& Cignacchi, M. (2009). Groups in space: stereotypes and the spatial agency bias. Journal of Experimental Social Psychology, 45.3: 496-504.

McFadden, Pat (2016, September 5). Brexit means what?. Retrieved from https://www. open-britain.co.uk/brexit_means_what

McNeill, David (1992). Hand and Mind: What Gestures Reveal about Thought. Chicago: Chicago University Press.

McNeill, David (2005). Gesture and Thought. Chicago: Chicago University Press.

Meibauer, Jörg (2008). Tautology as presumptive meaning. Pragmatics \& Cognition 16.3: 439-470.

Min, Shang-Chao (2008). Study on the differences of speech act of criticism in Chinese and English. US-China Foreign Language 6.3: 74-77.

Mompean, Jose A. (2004). Category overlap and neutralization: The importance of speakers' classifications in phonology. Cognitive Linguistics 15.4: 429-469.

Mompean, Jose A. (2006). The phoneme as a basic-level category: Experimental evidence from English. International Journal of English Studies 6.2: 141-172.

Mompean, Jose A. (2014). Cognitive linguistics and phonology. In John Taylor and Jeannette Littlemore (eds), The Bloomsbury Companion to Cognitive Linguistics (pp. 253-276). London: Bloomsbury Publishing.

Moseley, Tom (2016, December 25). The rise of the word Brexit. BBC News. Retrieved from https://www.bbc.com/news/uk-politics-37896977

Müller, Cornelia, Alan Cienki, Ellen Fricke, Silva Ladewig, David Mcneill, and Sedinha Teßendorf (eds.) (2013), Body-Language-Communication: An International Handbook on Multimodality in Human Interaction. Volume 1 (Handbooks of Linguistics and Communication Science 38.1). Berlin: Mouton.

Okamoto, Shigeko (1993). Nominal repetitive constructions in Japanese: The 'tautology' controversy revisited. Journal of Pragmatics 20.5: 433-466.

Outhwaite, William (ed.) (2017). Brexit: Sociological Responses. London: Anthem Press.

Pagán Cánovas, Cristobal and Javier Valenzuela (2017). Timelines and multimodal constructions: Facing new challenges. Linguistic Vanguard 3(s1). DOI 10.1515/lingvan-2016-0087

Panther, Klaus-Uwe and Linda Thornburg (1998). A cognitive approach to inferencing in conversation. Journal of Pragmatics 30(6): 755-769.

Panther, Klaus-Uwe and Linda Thornburg (2005). Motivation and convention in some speech act constructions: A cognitive linguistic approach. In Sophia Marmaridou, Kiki Nikifori- 
dou, and Eleni Antonopoulou (eds), Reviewing Linguistic Thought: Converging Trends in the 21st Century (pp. 53-76). Berlin: Mouton de Gruyter.

Partington, Alan (2008). The armchair and the machine: Corpus-assisted discourse studies (CADS). In C. Taylor Torsello, Katherine Ackerley, and Erik Castello (eds), Corpora for University Language Teachers (pp. 95-118). Bern: Peter Lang.

Pérez-Hernández, Lorena (2012). Saying something for a particular purpose: Constructional compatibility and constructional families. RESLA 25: 189-210.

Pérez-Hernández, Lorena (2013). Illocutionary constructions: (multiple source)-in-target metonymies, illocutionary ICMs, and specification links. Language and Communication 33: $128-149$.

Pérez-Hernández, Lorena and Francisco J. Ruiz de Mendoza (2011). A Lexical-Constructional Model account of illocution. Vigo International Journal of Applied Linguistics 8: 99-137.

Radden, Günter and Zoltán Kövecses (1999). Towards a theory of metonymy. In Klaus-Uwe Panther and Günter Radden (eds), Metonymy in Language and Thought (pp. 17-59). Amsterdam: John Benjamins.

Rhodes, Russell (2009). A cross-linguistic comparison of tautological constructions with special focus on English. Unpublished manuscript. Retrieved from https://pdfs.semanticscholar.org/afc4/5668665b4ce2f18795acbc1b06d0f3393dce.pdf

Riley-Smith, Ben (2018, August 6). Arguments made for and against Brexit during the EU referendum campaign. The Telegraph. Retrieved from https://www.telegraph.co.uk/politics/0/arguments-made-against-brexit-eu-referendum-campaign/

Ross, Daniel (2018). Small corpora and low-frequency phenomena: try and beyond contemporary, standard English. Corpus, 18 http://journals.openedition.org/corpus/3574

Ruiz de Mendoza Ibáñez, Francisco J. and Annalisa Baicchi (2007). Illocutionary constructions: Cognitive motivation and linguistic realization. In Istvan Kecskés and Laurence Horn (eds), Explorations in Pragmatics: Linguistic, Cognitive, and Intercultural Aspects (pp. 95-127). Berlin: Mouton de Gruyter.

Santiago, J., Lupiáñez, J., Pérez, E., \& Funes, M. J. (2007). Time (also) flies from left to right. Psychonomic Bulletin \& Review 14: 512-516

Schank, Roger C. and Robert P. Abelson (1977). Scripts, Plans, Goals and Understanding: An Inquiry into Human Knowledge Structures. Hillsdale, NJ: Lawrence Erlbaum Associates.

Schmid, Hans-Jörg (2016). A framework for understanding linguistic entrenchment and its psychological foundations. In Hans-Jörg Schmid (ed.), Entrenchment and the Psychology of Language Learning. How We Reorganize and Adapt Linguistic Knowledge (pp. 9-36). Boston, MA: APA and Walter de Gruyter.

Schnapper, Pauline (2018). Brexit, or Theresa May's headache. Observatoire de la Société Britannique 21: 21-34.

Searle, John (1975). Indirect speech acts. In P. Cole and J. L. Morgan (eds), Speech Acts (pp. 59-82). New York: Academic Press.

Shattuck-Hufnagel, Stefanie, Ada Ren, Mili Mathew, Yvan Yuen, and Katherine Demuth (2016). Non-referential gestures in adult and child speech: Are they prosodic? In Proceedings of the International Conference on Speech Prosody. International Speech Communication Association (ISCA), Vol. Baixas. pp. 836-839.

Steen, Francis and Mark Turner (2013). Multimodal Construction Grammar. In Michael Borkent, Barbara Dancygier, and Jennifer Hinnell (eds.), Language and the Creative Mind (pp. 255-274). Stanford, CA: CSLI Publications. 
Stefanowitsch, Anatol (2003). A construction-based approach to indirect speech acts. In Klaus-Uwe Panther and Linda L. Thornburg (eds), Metonymy and Pragmatic Inferencing (pp. 105-126). Amsterdam: John Benjamins.

Szymanek, Bogdan (2015). Remarks on tautology in word-formation. In Laurie Bauer, Lívia Körtvélyessy, and Pavol Štekauer (eds.), Semantics of Complex Words [Studies in Morphology 3] (pp. 143-161). New York: Springer.

Valenzuela, Javier, Joseph Hilferty and Mar Garachana (2005). On the reality of constructions. The Spanish reduplicative-topic construction. Annual Review of Cognitive Linguistics 3: 201-215.

van Dijk, Teun A. (1997). What is political discourse analysis? Belgian Journal of Linguistics 11: $11-52$.

Vassilaki, Evgenia (2017). Cognitive motivation in the linguistic realization of requests in Modern Greek. In Angeliki Athanasiadou (ed.), Studies in Figurative Thought and Language (pp. 105-124). Amsterdam: John Benjamins.

Vigliocco, Gabriella, Pamela Perniss, and David Vinson (2014). Language as a multimodal phenomenon: Implications for language learning, processing and evolution. Philosophical Transactions of the Royal Society B 369(1651): 20130292. doi: 10.1098/rstb.2013.0292

Ward, Gregory L., and Julia Hirschberg (1991). A pragmatic analysis of tautological utterances. Journal of Pragmatics 15.6: 507-520.

Wierzbicka, Anna (1987). Boys will be boys: 'Radical semantics' vs. 'radical pragmatics'. Language 63.2: 95-114.

Wincott, Daniel, John Peterson, and Alan Convery (2017). Introduction: Studying Brexit's causes and consequences. The British Journal of Politics and International Relations 19.3: 429-433. Special issue on Brexit.

Ziem, Alexander (2017). Do we really need a Multimodal Construction Grammar? Linguistics Vanguard 3(s1), DOI: https://doi.org/10.1515/lingvan-2016-0095

\section{Appendix}

a) Instances of $B m B$ and related uses by speaker, chronological date of production and link.

\begin{tabular}{|l|c|l|}
\hline \multicolumn{1}{|c|}{ Speaker } & Date & \multicolumn{1}{c|}{ Link } \\
\hline Theresa May & 30 Jun 2016 & https:/www.youtube.com/watch?v=yCPmwjywLNY \\
\hline Theresa May & 11 Jul 2016 & https://www.youtube.com/watch?v=KMek1okqphs \\
\hline Theresa May & 11 Jul 2016 & https://www.youtube.com/watch?v=jClv7yIJFaY \\
\hline Theresa May & 11 Jul 2016 & https://www.youtube.com/watch?v=HhyaJMUIOqI \\
\hline Amber Rudd & 12 Jul 2016 & https://www.youtube.com/watch?v=b-ZO2pQNtog\&t=8s \\
\hline Nigel Farage & 13 Jul 2016 & https://www.youtube.com/watch?v=N4ZNdko2D14 \\
\hline Sajid Javid & 18 Jul 2016 & https://www.youtube.com/watch?v=b-ZO2pQNtog\&t=8s \\
\hline Theresa May & 20 Jul 2016 & $\begin{array}{l}\text { https://thelincolnite.co.uk/2016/07/lincolnshire-mp-invites- } \\
\text { prime-minister-make-day-special-rejecting-single-market/ }\end{array}$ \\
\hline
\end{tabular}




\begin{tabular}{|c|c|c|}
\hline Speaker & Date & Link \\
\hline Theresa May & $20 \mathrm{Jul} 2016$ & $\begin{array}{l}\text { https://www.theguardian.com/politics/2016/aug/31/no- } \\
\text { staying-in-eu-by-back-door-theresa-may-brexit }\end{array}$ \\
\hline Theresa May & 21 jul 2016 & $\begin{array}{l}\text { https://www.reuters.tv/v/C9I/2016/07/21/hollande-tells- } \\
\text { may-to-start-brexit-soon }\end{array}$ \\
\hline Nicola Sturgeon & $25 \mathrm{Jul} 2016$ & https://www.youtube.com/watch?v=ZcMcII_PQTs \\
\hline Theresa May & 31 Aug 2016 & https://www.youtube.com/watch?v=jt-KV05BvaA \\
\hline Andrew Marr & 04 Sept 2016 & https://www.youtube.com/watch?v=uNBKCAOC1qc \\
\hline Journalist A & 05 Sept 2016 & \multirow{2}{*}{$\begin{array}{l}\text { https://www.express.co.uk/videos/5112787972001/Theresa- } \\
\text { May-I-ve-been-saying-Brexit-means-Brexit-because-it-does }\end{array}$} \\
\hline Theresa May & 05 Sept 2016 & \\
\hline Journalist B & 05 Sept 2016 & \multirow{2}{*}{ https://www.youtube.com/watch?v=K0M2UGRmk_A } \\
\hline Theresa May & 05 Sept 2016 & \\
\hline Rowena Mason & 11 Sept 2016 & https://www.youtube.com/watch?v=6asme48xrOg \\
\hline Boris Johnson & 11 Sept 2016 & https://www.youtube.com/watch?v=nyuzyx8UR4E \\
\hline Charlie Elphicke & 14 Sept 2016 & \multirow{2}{*}{$\begin{array}{l}\text { https://parliamentlive.tv/event/index/8772c982-a9b9-458b- } \\
\text { b4f7-2419ed1d6bf8?in=12:03:31 }\end{array}$} \\
\hline Steward Hosie & 14 Sept 2016 & \\
\hline Nick Clegg & 19 Sept 2016 & https://www.youtube.com/watch?v=QhT3PTKQ-sQ \\
\hline Theresa May & 02 Oct 2016 & https://www.youtube.com/watch?v=EddGOL3xi8s \\
\hline Patience Wheatcroft & 27 Oct 2016 & https://www.youtube.com/watch?v=t-NZF1KGZz4 \\
\hline Jeremy Corbyn & 28 Oct 2016 & \multirow{2}{*}{ https://www.youtube.com/watch?v=-103NVQf-D8 } \\
\hline Theresa May & 28 Oct 2016 & \\
\hline Tom Walker & 30 Oct 2016 & https://www.youtube.com/watch?v=qd6V3AWQdHY \\
\hline Boris Johnson & 02 Nov 2016 & $\begin{array}{l}\text { https://www.theguardian.com/politics/2016/nov/03/brexit- } \\
\text { will-be-titanic-success-says-boris-johnson }\end{array}$ \\
\hline Donald Trump & 07 Nov 2016 & https://www.youtube.com/watch?v=WX9mviKUf9Q \\
\hline Stella Creasy & 5 Feb 2017 & https://www.youtube.com/watch?v=SHuDldYOpdA \\
\hline Nigel Farage & 21 Jun 2017 & $\begin{array}{l}\text { https://www.youtube.com/ } \\
\text { watch?v=OCCKP3Q3228\&t=424s }\end{array}$ \\
\hline Audience member & 01 Feb 2018 & https://www.youtube.com/watch?v=a-ZuQsHoWt4 \\
\hline Theresa May & 02 Jul 2018 & $\begin{array}{l}\text { https://www.bbc.com/news/av/uk-politics-44689824/ } \\
\text { theresa-may-brexit-means-brexit-does-mean-brexit }\end{array}$ \\
\hline Nigel Farage & $11 \mathrm{Jul} 2018$ & https://www.youtube.com/watch?v=gkoNFu0z2J4 \\
\hline Theresa May & 18 Jul 2018 & https://www.youtube.com/watch?v=NfEmy0aiJNY \\
\hline
\end{tabular}




\begin{tabular}{|l|c|l|}
\hline \multicolumn{1}{|c|}{ Speaker } & Date & \multicolumn{1}{c|}{ Link } \\
\hline David Jones & 28 Jul 2017 & $\begin{array}{l}\text { https://archive.org/details/BBCNEWS_20170628_221500_ } \\
\text { Newsnight/start/660/end/720 }\end{array}$ \\
\hline Priti Patel & 26 Nov 2018 & $\begin{array}{l}\text { https://www.express.co.uk/news/uk/1050635/brexit-news- } \\
\text { latest-deal-theresa-may-priti-patel-UK-EU }\end{array}$ \\
\hline Nigel Farage & 15 Nov 2018 & $\begin{array}{l}\text { https://www.express.co.uk/news/uk/1045646/Brexit-News- } \\
\text { Nigel-Farage-video-Theresa-May-Brexit-deal-brexit-means- } \\
\text { remain }\end{array}$ \\
\hline
\end{tabular}

c) Excerpts as listed in the main text.

(1) Donald Trump (7 November 2016, at a rally in North Carolina).

"This election will decide whether we are ruled by a corrupt political class... or whether we're ruled by the people. We're gonna be ruled by the people, folks... tomorrow's gonna be a very historic day. I really believe that. I think it's gonna... I think it's gonna be Brexit plus plus plus. Does that make sense? Plus, plus, plus. It'll be amazing."

(2) Theresa May (30 June 2016, speech announcing her leadership candidacy in London).

"Brexit means Brexit. The campaign was fought. The vote was held. Turnout was high. And the public gave their verdict. There must be no attempts to remain inside the EU, no attempts to rejoin it through the backdoor and no second referendum. The country voted to leave the EU and it is the duty of the government and parliament to make sure we do just that."

(3) Sajid Javid (18 July 2016, House of Commons).

"First, the hon. Gentleman should just accept that Brexit means Brexit. The focus of the whole House should be on how best to deliver that."

(4) Theresa May (11 July 2016, speech at the Conservative Party conference, Birmingham).

"First. Our country needs strong, proven leadership, to steer us through this time of economic and political uncertainty, and to negotiate the best deal for Britain as we leave the EU, and forge a new role for ourselves in the world. Because Brexit means Brexit and we're going to make a success of it. Second, we need to unite our party and our country."

(5) Theresa May (11 July 2016, speech at the Conservative Party conference, Birmingham).

"Well, I couldn’t be clearer. Brexit means Brexit. And we're going to make a success of it."

(6) Theresa May (11 July 2016, first speech as Tory leader, outside the Houses of Parliament).

"Brexit means Brexit and we are going to make a success of it." 
(7) Theresa May (20 July 2016, at a press conference with Angela Merkel, Berlin). "I've been clear that Brexit means Brexit, and the UK is going to make a success of it."

(8) Theresa May (21 July, at a joint press conference with François Hollande, Paris). "As I have said Brexit means Brexit and I firmly believe we will make a success of it, not just for the UK but for our European partners too."

(9) Theresa May (31 August 2016, at a cabinet meeting, London).

"We must continue to be very clear that Brexit means Brexit, that we're going to make a success of it."

(10) Theresa May (2 October 2016, speech at Tory conference, Birmingham).

"Even now, some politicians - democratically-elected politicians - say that the referendum isn't valid, that we need to have a second vote. Others say they don't like the result, and they'll challenge any attempt to leave the European Union through the courts. But come on. The referendum result was clear. It was legitimate. It was the biggest vote for change this country has ever known. Brexit means Brexit - and we're going to make a success of it."

(11) Amber Rudd (12 July 2016, debate at the House of Commons).

"I also want to respond to the point made by my hon. Friend Dr. Murrison: it may have escaped some people's notice, but I did campaign on the other side of the EU referendum. I do agree with him, however, that we must move on: Brexit means Brexit and, as my Rt. Hon. friend Mrs. May said, we will make a success of it.”

(12) Charlie Elphicke (14 September 2016, while presenting a motion in the House of Commons).

"....The House knows that the position of the Government is very clear. Brexit means Brexit and we will make a success of it, but also Brexit means Brexit and we need to get on with it..."

(13) Boris Johnson (2 November 2016, speech at the Spectator Awards, London). "In the words of our great PM, they understand that Brexit means Brexit and we are going to make a titanic success of it."

(14) Andrew Marr (4 September 2016, on BBC One The Andrew Marr Show).

"Now, you've already mentioned the B-word, so let's talk about Brexit. 'Brexit means Brexit,' you said, but what does Brexit mean?"

(15) Journalist 1, Theresa May (5 September 2016, at a G20 press conference, Hangzhou, China).

J1: “... and obviously you've been saying Brexit means Brexit since the leadership campaign but clearly some world leaders here wanted a bit more in terms of predictability for their businesses, their industries..."

TM: "Well, the reason I've been saying Brexit means Brexit is precisely because it means it does. And, to be very clear, that we are going to deliver on the wishes of the British people and we will respect the vote that took place on the $23^{\text {rd }}$ of June..." 
(16) Journalist 2, Theresa May (5 September 2016, at a G20 press conference with Barack Obama, Hangzhou, China).

J2: “...And for the PM, you said that Brexit means Brexit, but I wonder if you could be a bit more specific. Could you categorically rule out the UK staying within the EU?"

TM: "One of the questions you asked me about Brexit - yes, Brexit does indeed mean Brexit. On the $23^{\text {rd }}$ of June, the people in the UK voted for the UK to leave the European Union. The Government respects that decision... and we will put that into practice. So there'll be no second referendum, to attempt to turn the clock back, no attempt and try to get out of this. The UK will be leaving the EU."

(17) Rowena Mason (11 September 2016, on Sky News Murnaghan).

"Well, one of the problems Theresa May's got with this phrase 'Brexit means Brexit' is that that doesn't really mean anything at all and she's not explaining what she wants and so it's left this vacuum for other people to fill it..."

(18) Patience Wheatcroft (27 October 2016, on BBC Two Daily Politics).

"The country voted, not by an overwhelming majority, but nevertheless the country voted in favour of Brexit, not knowing what Brexit means, and we're still told Brexit means Brexit. We don't know what it means..."

(19) Jonathan Pie [Tom Walker] (30 October 2016, Youtube).

"Okay, Brexit means Brexit but I want to know what it means. I want the details, and Theresa May, she's saying nothing."

(20) Edward Leigh, Theresa May (20 July 2016, at PM's Questions in the House of Commons).

EL: "I agree with the PM [cheers and laughter]. We're leaving the EU and we're going to make a success of it. So will the PM make my day special by saying she is prepared to reject staying in the single regulated market and offering instead to our friends in Europe a free trade deal, very much in their interest? Let's take back control."

TM: “... My Honourable friend just made my day... [a]nd can I assure him as we look at the results of the referendum I'm very clear Brexit does mean Brexit. As he says, we will make a success of it. What we need to do in negotiating the deal is to ensure that we listen to what people have said about the need for controls on free movement. But we also negotiate the right deal, and the best deal, of trade in goods and services for the British people."

(21) Boris Johnson (Broadcast on September 2016, ad of the Change Britain group). "Brexit means Brexit and that means delivering on their instructions and restoring UK control over our laws, borders, money, and trade."

(22) Nicola Sturgeon (25 July 2016, speech at the Institute for Public Policy Research think tank, Edinburgh).

“...we have a new PM and a new UK Government, but we don't yet have any clear explanation of what a Leave vote means in practice. If we can read anything from the early signs, whether from government appointments or from initial pronounce- 
ments it is... that the UK is heading towards a hard rather than a soft Brexit... But while Brexit means Brexit is intended to sound like a strong statement of intent, it is, in truth, just a soundbite that masks a lack of any clear sense of direction".

(23) Steward Hosie (14 September 2016, parliamentary exchange between Charlie Elphicke and Hosie).

"...the hon. Gentleman made a pitch to leave now because, he said, "Brexit means Brexit and we will make a success of it"; I think I am quoting accurately. The problem... is that when the PM - the leader of Government, the high held yin of the Tory party - is asked, "If Brexit means Brexit, does it mean we will be staying in the single market?", she does not know... So on the basis that "Brexit means Brexit" is no more than a meaningless campaigning expression...".

(24) Theresa May, Jeremy Corbyn (28 October 2016, House of Commons).

TM: "In relation to the issue of clarity, on the aims that the Government has in relation to Brexit, I have been very clear and I will be very clear again. The... (general noise)..."

JC: "I thought for a moment the PM was going to say Brexit means Brexit again $(($ laughter $)) \ldots$ there are others... ((general noise $))$ ((Corbyn gestures to PM)) I'm sure (.) I'm sure she'll tell us one day what it actually means..."

TM: " $\ldots$ the leader of the opposition tries to poke fun at the phrase of Brexit means Brexit but the whole point is this (general noise)... it's this government that is listening to the voice of the British people (cheers of approval)... Brexit means Brexit and that means we're coming out of the European Union ((general noise)) what the Rt Hon gentleman tries to be doing is frustrating the will of the British people (cheers of approval) by saying that Brexit means something completely different."

(25) Stella Creasy (5 February 2017, on Sky's Sophie Ridge on Sunday).

“...Just some honesty with the people, the Government's had to be pulled kicking and screaming to get in parliament into this process. The PM has spent seven months just saying Brexit means Brexit, means breakfast, mean breakfast (laughs), you know, no wonder that gentleman in Bristol is really, really worried. Same again on this issue about whether it's about EU nationals, whether it's about the role of parliament in the deal..."

(26) Nick Clegg (19 September 2016, Autumn Liberal Democrat conference, Brighton).

“'Brexit means Brexit' - have you ever heard a more inane and disingenuous phrase in modern British political discourse?... It is used, of course, robotically by Theresa May to cover up, to camouflage the indignity of the paralysis at the heart of this Conservative government... paralysis because of the tension between their wish to trim freedom of movement and their wish to have access to the single market."

(27) Nigel Farage (13 July 2016, outside the Houses of Parliament).

"With an irony, in a remainer, becoming the PM, she said Brexit means Brexit. Let's hope she means it." 
(28) Nigel Farage (21 July 2017, BBC documentary Brexit means Brexit).

"...Mrs. May backs the Remain side but does so in a very lukewarm manner. She then becomes the PM and says Brexit means Brex(...) I think, gosh!... This is great! And then, five months go by and nothing happens. I want to see some direction because I'm hearing this new Chancellor fella, Hammond... saying we might stay in the customs union. Boris (Johnson) saying we are definitely leaving. The left hand and the right hand, clearly, are not quite sure what's going on..."

(29) Nigel Farage (11 July 2018, interview on Fox News).

"...now, what Mrs. May has done is, frankly, to behave totally dishonestly with the British public. She told us 'Brexit means Brexit'. We will take back control of our laws, our borders, and our money, and the compromise that she put forward at Chequers last week, the PM's country home, frankly was a betrayal of those things."

(30) Desmond Swayne, Theresa May (2 July 2018, House of Commons).

DS: "Will Brexit be recognisable as Brexit?"

TM: "Yes, can I say to my Honourable friend, there's been much sort of jocularity about the term 'Brexit means Brexit' but it does mean Brexit ((laughter))... people want to ensure that we take back control of our borders, our laws and that we no longer continue to send vast sums of money to the European Union each year... but we will be ensuring that we're able to trade with the European Union and set an independent trade policy which allows us to negotiate good trade deals with the rest of the world".

(31) Priti Patel (26 November 2018, interview on Sky News, outside the Houses of Parliament).

"...when the government came together, two years ago, after the referendum, we were told that Brexit means Brexit. We were told that we would, yes, be leaving under many terms that you and your viewers have been hearing about day in day out, but we were also told that no deal is better than a bad deal. This deal is going to keep us tied into the European Union." (25 November 2018, outside the Houses of Parliament).

(32) Nigel Farage (15 November 2018 on LBC radio).

"When will we end free movement? When will we get our fisheries back? when will be able to make our own laws? Well, it looks like 2030 is now the date that's been decided on the sum of it, and why should that change for all the rest of it. I simply cannot believe we have got a PM who stands up and says Brexit means Brexit, but what she really means is Brexit means Remain. I'm absolutely... I'm so angry at that I can barely put it into words..."

(33) Andrea Jenkyns, Theresa May (18 July 2018, at PMQs in a House of Commons).

AJ: "Can the PM inform the house, at what point it was decided that Brexit means Remain? ((groans))."

TM: "Can I... can I say to my Honourable friend: at absolutely no point. Because Brexit continues to mean Brexit ((cheers))." 
(34) Evan Davis, David Jones (28 July 2017, on current affairs programme Newsnight, BBC Two).

ED: “....Loads of swing voters who might have voted Tory voted for Jeremy Corbyn's Labour Party because they so detested Theresa May's version of Brexit. Metropolitan, liberal Remainers.... said 'we cannot vote for Theresa May because we don't like her Brexit'... you can't say that anybody who voted Labour was endorsing Theresa May's Brexit..."

DJ: "Brexit, actually, to coin a phrase, does mean Brexit. We have already set ourselves on the course for leaving the European Union."

(35) Theresa May (5 September 2016, at a G20 press conference with Barack Obama, Hangzhou, China).

"One of the questions you asked me about Brexit - yes, Brexit does indeed mean Brexit. On the $23^{\text {rd }}$ of June, the people in the UK voted for the UK to leave the European Union..."

(36) Theresa May (20 July 2016, at TM's first PM's Questions in the House of Commons).

“...My Honourable friend... can I assure him as we look at the results of the referendum I'm very clear Brexit does mean Brexit..."

(37) Desmond Swayne, Theresa May (2 July 2018, House of Commons).

SW: "Will Brexit be recognisable as Brexit?"

TM: "Yes, can I say to my Honourable friend, there's been much sort of jocularity about the term 'Brexit means Brexit' but it does mean Brexit ((laughter))."

(38) Evan Davis, David Jones (28 July 2017, on current affairs programme Newsnight, BBC Two).

ED: “...Loads of swing voters who might have voted Tory voted for Jeremy Corbyn's Labour Party because they so detested the Theresa May version of Brexit..." DJ: "Brexit, actually, to coin a phrase, does mean Brexit. We have already set ourselves on the course for leaving the European Union."

(39) Andrea Jenkyns, Theresa May (18 July 2018, at PMQs in a House of Commons).

AJ: "Can the PM inform the house, at what point it was decided that Brexit means Remain? ((groans))."

TM: "Can I... can I say to my Honourable friend: at absolutely no point. Because Brexit continues to mean Brexit ((cheers))."

(40) Justine Greening, audience member (1 February 2018, BBC One Question time).

JG: “...what I'm saying, sir, is that if we want to actually get a sustainable Brexit, then we're going to have to have some give-and-take and we're gonna have to find a way of approaching Brexit that, genuinely, can bring..."

AM: "You're characterising Brexiteers as extreme. Brexit is Brexit. It's not difficult to understand. It's Brexit. Don't tell us... I'm fed up of hearing this from politicians; don't tell us that those 'ardent Brexiteers'... we just want Brexit. It means 
getting out of the single market, governing ourselves, controlling our borders. This is not rocket science, it's called Brexit."

(41) Theresa May (30 June 2016, speech announcing her leadership candidacy in London).

"Brexit means Brexit. The campaign was fought. The vote was held. Turnout was high..."

(42) Theresa May (11 July 2016, speech at the Conservative Party conference, Birmingham).

“...Because Brexit means Brexit and we're going to make a success of it. Second, we need to unite our party and our country."

(43) Theresa May (11 July 2016, first speech as Tory leader, outside the Houses of Parliament).

"Brexit means Brexit and we are going to make a success of it."

(44) Journalist 2 (5 September 2016, at a G20 press conference with Barack Obama, Hangzhou, China).

"...And for the PM, you said that Brexit means Brexit, but I wonder if you could be a bit more specific. Could you categorically rule out the UK staying within the EU?"

(45) Rowena Mason (11 September 2016, on Sky News politics programme Murnaghan).

"Well, one of the problems Theresa May's got with this phrase 'Brexit means Brexit' is that that doesn't really mean anything at all and she's not explaining what she wants and so it's left this vacuum for other people to fill it..."

(46) Jeremy Corbyn (28 October 2016, House of Commons).

"I thought for a moment the PM was going to say Brexit means Brexit again ((laughter))... there are others... ((general noise)) ((Corbyn gestures to PM)) I'm sure (.) I'm sure she'll tell us one day what it actually means..."

(47) Jonathan Pie [Tom Walker] (30 October 2016, Youtube).

"Okay, Brexit means Brexit but I want to know what it means. I want the details, and Theresa May, she's saying nothing."

(48) Theresa May (31 August 2016, at a cabinet meeting, London).

"We must continue to be very clear that Brexit means Brexit, that we're going to make a success of it."

\section{Acknowledgements}

This work was funded by MICINN projects PGC2018-095050-B-I00 and PGC2018097658-B-I00 (Ministerio de Ciencia, Innovación y Universidades, Spanish Government) 